\title{
Article \\ Palladium-Catalyzed Dehydrogenative C-2 Alkenylation of 5-Arylimidazoles and Related Azoles with Styrenes
}

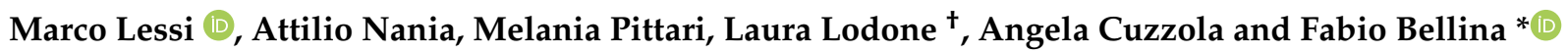 \\ Dipartimento di Chimica e Chimica Industriale, Via Moruzzi 13, 56124 Pisa, Italy; marco.lessi@unipi.it (M.L.); \\ a.nania@studenti.unipi.it (A.N.); m.pittari@studenti.unipi.it (M.P.); laura.lodone@sgs.com (L.L.); \\ angela.rosa.cuzzola@unipi.it (A.C.) \\ * Correspondence: fabio.bellina@unipi.it; Tel.: +39-0502219282 \\ + Present address: SGS Italia S.p.A., Via Colombara 115, 30176 Malcontenta, VE, Italy.
}

Citation: Lessi, M.; Nania, A.;

Pittari, M.; Lodone, L.; Cuzzola, A.;

Bellina, F. Palladium-Catalyzed

Dehydrogenative C-2 Alkenylation of 5-Arylimidazoles and Related Azoles with Styrenes. Catalysts 2021, 11, 762. https://doi.org/10.3390/catal 11070762

Academic Editor: Corinne Fruit

Received: 27 May 2021

Accepted: 21 June 2021

Published: 23 June 2021

Publisher's Note: MDPI stays neutral with regard to jurisdictional claims in published maps and institutional affiliations.

Copyright: (c) 2021 by the authors. Licensee MDPI, Basel, Switzerland. This article is an open access article distributed under the terms and conditions of the Creative Commons Attribution (CC BY) license (https:// creativecommons.org/licenses/by/ $4.0 /)$.

\begin{abstract}
The construction of carbon-carbon bonds by direct involvement of two unactivated carbon-hydrogen bonds, without any directing group, ensures a high atom economy of the entire process. Here, we describe a simple protocol for the $\mathrm{Pd}(\mathrm{II}) / \mathrm{Cu}(\mathrm{II})$-promoted intermolecular cross-dehydrogenative coupling (CDC) of 5-arylimidazoles, benzimidazoles, benzoxazole and 4,5diphenylimidazole at their C-2 position with functionalized styrenes. This specific CDC, known as the Fujiwara-Moritani reaction or oxidative Heck coupling, also allowed the C-4 alkenylation of the imidazole nucleus when both 2 and 5 positions were occupied.
\end{abstract}

Keywords: C-H activation; imidazoles; Fujiwara-Moritani reaction; dehydrogenative coupling; oxidative Heck coupling; styrenes; palladium catalysis; copper salts

\section{Introduction}

Transition metal-catalyzed carbon-carbon bond-forming reactions that occur by the breaking of carbon-hydrogen bonds are attracting increasing interest in modern synthetic organic chemistry since this approach does not require any pre-activation of the starting materials [1-11]. When compared with conventional cross-coupling methodologies that require the use of organic halides and/or preformed organometallic reagents, this strategy, known as cross dehydrogenative coupling (CDC), allows the obtainment of a high degree of atom economy and structural complexity in the target molecule, while ensuring high chemoselectivity. In addition, unlike traditional cross-couplings, the possibility of avoiding the use of metals and halogens in stoichiometric quantities reduces the production of inorganic waste.

In this context, the palladium-catalyzed cross-coupling between (hetero)arenes and terminal alkenes, known as the Fujiwara-Moritani reaction or even oxidative Heck coupling [12-14],represents one of the most classic CDC reactions for the functionalization of (hetero)arenes [2-4,6,11,15-17].

Although this reaction was first reported in 1967 [12], and thus historically precedes the development of the Mizoroki-Heck alkenylation [18,19], problems related to poor regioselectivity and the need to use oxidants have in the past limited its application in favor of both the aforementioned Mizoroki-Heck alkenylation and the traditional cross-coupling procedures, and also the most recent direct alkenylation of aromatic $\mathrm{C}-\mathrm{H}$ bonds, also catalyzed by transition metals, involving alkenyl halides [20-26]. If problems associated with the use of oxidants in stoichiometric quantities can be overcome by the latest electrochemical approaches [27-30], the achievement of high regioselectivity is still often an issue to be solved. In this regard, however, it is important to note that when the reaction is conducted using a heteroarene as a partner, the presence of one or more heteroatoms leads to an innate distinction among the different $\mathrm{C}-\mathrm{H}$ bonds, thus allowing, with appropriate optimization of the reaction conditions, the selective involvement of a specific Csp2-H bond. 
Due to our continuous interest in the development of methods for the palladiumcatalyzed regioselective $\mathrm{C}-\mathrm{H}$ functionalization of azoles and in their application to the preparation of new organic materials [31-36], we recently decided to evaluate the FujiwaraMoritani reaction as an atom economy way to achieve the preparation of styryl-substituted imidazoles. Our interest in this investigation was also given by the fact that while several procedures are reported for the dehydrogenative alkenylation of indoles, pyrroles, and oxazoles $[4,11]$, to the best of our knowledge only two papers reported the synthesis of styryl-substituted imidazoles by dehydrogenative alkenylation, both using only unfunctionalized styrene as the coupling partner.

In a study mainly devoted to the dehydrogenative C-2 alkenylation of benzoxazole, in 2014, Ong and coworkers reported the synthesis of 1-methyl-2-styrilimidazole and 1-methyl2-styrilbenzimidazole starting from the corresponding 1-methylazoles and 2.5-5 equiv of styrene, in the presence of $10-20 \mathrm{~mol} \%$ palladium(II) trifluoroacetate $\left(\mathrm{Pd}(\mathrm{TFA})_{2}\right)$ as the precatalyst, 15-30 mol\% 1,10-phenantroline (1,10-Phen) as the ligand, 1.0-2.0 equiv of silver(I) trifluoroacetate (AgTFA) as the oxidant, in toluene at $130{ }^{\circ} \mathrm{C}$ for $16 \mathrm{~h}$ (Scheme 1) [37].<smiles>C=C[CH+]c1nccn1C</smiles>

(2.5 equiv)
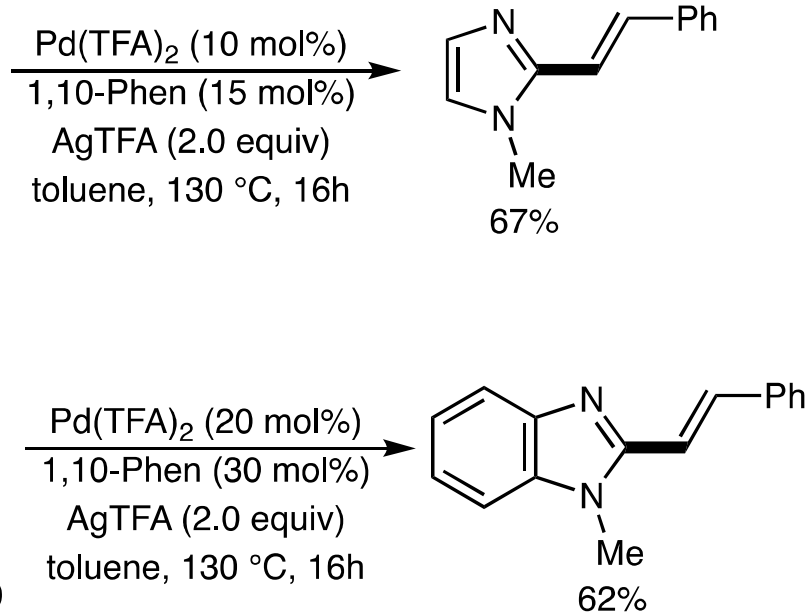

Scheme 1. Cross-dehydrogenative C-2 alkenylation of 1-methylimidazole and 1-methylbenzimidazole with styrene, according to Ong and co-workers [37].

In 2018, Joo and co-workers described a protocol for the regioselective C-5 alkenylation of 1-substituted imidazoles (Scheme 2) [38]. The optimized conditions involved the coupling of 1-methylimidazole with 2.0 equiv of styrene in the presence of $10 \mathrm{~mol} \%$ palladium(II) acetate ( $\mathrm{Pd}(\mathrm{OAc})_{2}, 2.0$ equiv potassium pivalate (KOPiv) in $N, N$-dimethylacetamide (DMA) at $120{ }^{\circ} \mathrm{C}$ for $24 \mathrm{~h}$ under an oxygen atmosphere. When 1,2-disubstituted imidazoles were used as the reaction partners, the authors found it better to perform the coupling using copper (II) acetate $\left(\mathrm{Cu}(\mathrm{OAc})_{2}\right)$ as the stoichiometric oxidant instead of oxygen, in dioxane at $100{ }^{\circ} \mathrm{C}$ for $15 \mathrm{~h}$.

In this paper, we are pleased to summarize our efforts in finding an effective and simple protocol for the dehydrogenative alkenylation of imidazole derivatives, which allowed us to develop a simple procedure for the dehydrogenative alkenylation of 5-aryl-1methylimidazoles and some related azoles with functionalized styrenes (Scheme 3). The optimized reaction conditions involve the use propanoic acid as the solvent at $120^{\circ} \mathrm{C}$, in the presence $\mathrm{Pd}(\mathrm{OAc})_{2}$ as the pre-catalyst and $\mathrm{Cu}(\mathrm{OAc})_{2}$ as the oxidant. 


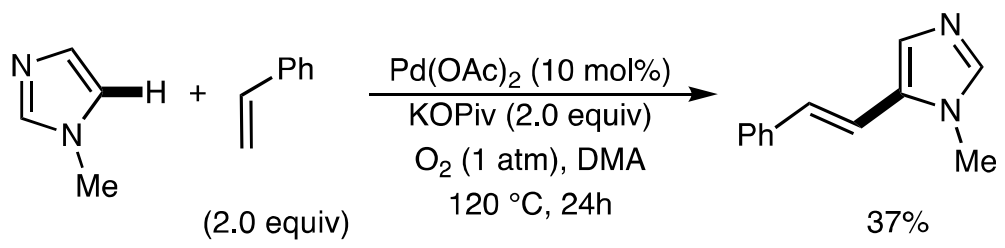<smiles>C=C[C+]c1cnc(C)n1P</smiles>

(3.0 equiv)

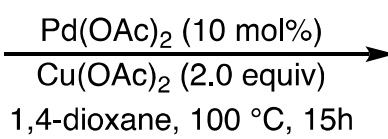

1,4-dioxane, $100{ }^{\circ} \mathrm{C}, 15 \mathrm{~h}$<smiles>Cc1ncc(/C=C/[Bi])n1P</smiles>

$$
\mathrm{R}=\mathrm{Bn}: 46 \%
$$$$
\mathrm{R}=\mathrm{SEM}: 57 \%
$$

Scheme 2. Cross-dehydrogenative C-5 alkenylation of 1-substituted imidazoles with styrene, according to Joo and co-workers [38].

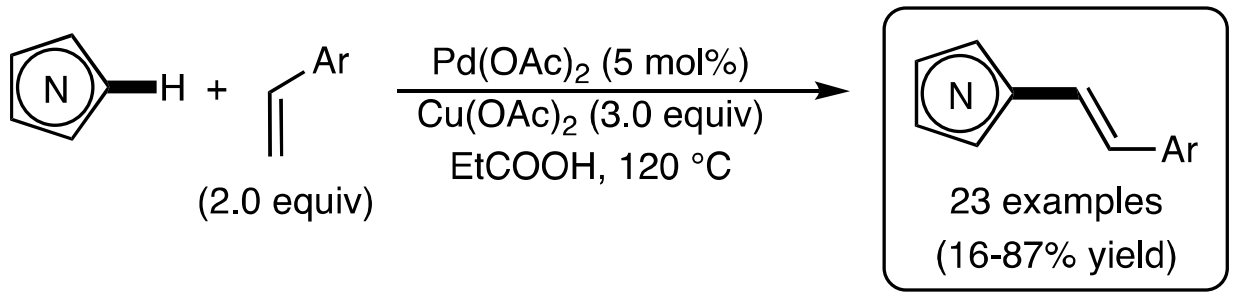

Scheme 3. Our protocol for the cross-dehydrogenative $\mathrm{Pd}(\mathrm{II}) / \mathrm{Cu}(\mathrm{II})$-mediated alkenylation of imidazoles.

\section{Results and Discussion}

\subsection{Screening of the Reaction Conditions}

At the onset of our study, we decided to test the efficiency of the Ong protocol by trying a dehydrogenative alkenylation of 5-(4-methoxyphenyl)-1-methyl- $1 \mathrm{H}$-imidazole (1a) with styrene (2a), chosen as model reaction partners. Hence, $\mathbf{1 a}$ and 2.5 equiv of $\mathbf{2 a}$ were reacted in the presence of $10 \mathrm{~mol} \% \mathrm{Pd}(\mathrm{TFA})_{2}, 15 \mathrm{~mol} \%$ 1,10-Phen and 2.0 equiv AgTFA (Scheme 4).

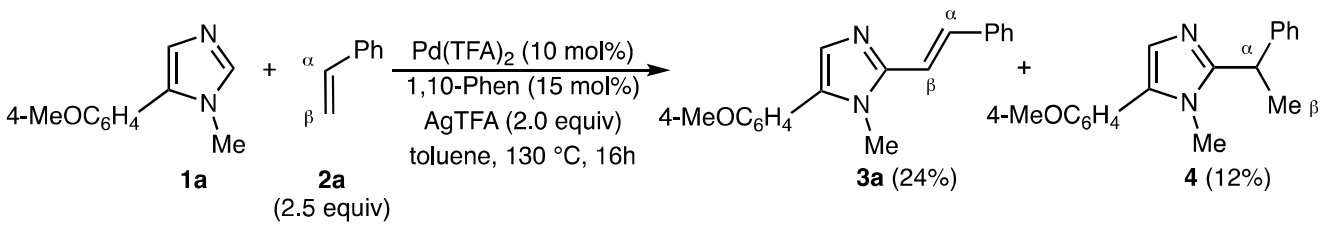

Scheme 4. Dehydrogenative alkenylation of imidazole 1a with styrene (2a) using the Ong protocol [37].

After stirring the reaction mixture for $16 \mathrm{~h}$ at $130{ }^{\circ} \mathrm{C}$ in toluene, an unsatisfactory $59 \%$ GLC conversion of 1 a was observed. Moreover, the required alkenyl-substituted imidazole 3 a was formed in a 58:42 GLC ratio with the 2-alkylimidazole 4 . These derivatives were isolated in 24 and $12 \%$ yields, respectively, and their structures confirmed by NMR analyses. The unexpected formation of compound 4 can be explained by admitting that the carbopalladation of styrene by the Pd-imidazole complex (resulting from the activation of the heteroaromatic $\mathrm{C} 2-\mathrm{H}$ bond, see later) occurred with incomplete regioselectivity [11].

An even worse result was observed when $\mathbf{1 a}$ and $\mathbf{2 a}$ were reacted using the Joo protocol [38], i.e., in the presence of $10 \mathrm{~mol} \% \mathrm{Pd}(\mathrm{OAc})_{2}$ and 2.0 equiv of $\mathrm{KOAc}$ in DMA 
under an oxygen atmosphere. In fact, the GLC conversion of $1 \mathrm{a}$ after $24 \mathrm{~h}$ at $120{ }^{\circ} \mathrm{C}$ was less than $15 \%$ (result not shown).

These unsatisfactory results prompted us to search for alternative reaction conditions. Considering that classical Fujiwara-Moritani protocols require the use of simple carboxylic acid (such as acetic acid) as the reaction solvent [3,13], and that many of the reported procedures for the dehydrogenative alkenylation of azoles have been carried out in acidic solvents $[4,11]$, we decided to start a screening of the reaction conditions using a carboxylic acid as the solvent and examining the influence of the nature of the solvent, the oxidant, and the palladium pre-catalyst on the reaction outcome.

Due to the fact that no protocols for the dehydrogenative alkenylation of imidazoles using acidic solvents were reported, we started our trial performing the reaction between imidazole 1a and styrene (2a) under reaction conditions very similar to those described by Miura and co-workers in 2010 for the regioselective C-5 dehydrogenative alkenylation of 2-substituted oxazoles and thiazoles [39]. Hence, 1a and 2.0 equiv of $\mathbf{2 a}$ were stirred at $120{ }^{\circ} \mathrm{C}$ in propionic acid $(\mathrm{EtCOOH})$, in the presence of $5 \mathrm{~mol} \%$ palladium(II) acetate $\left(\mathrm{Pd}(\mathrm{OAc})_{2}\right)$ and 3.0 equiv of silver(I) acetate (AgOAc) (entry 1, Table 1). After $24 \mathrm{~h}$ the expected C-2 alkenylated imidazole 3a was obtained in 33\% GLC yield, along with a higher molecular weight side product, that was preliminarily identified by GLC-MS and UPLC-MS analyses to be the bis-alkenylated imidazole 5a.<smiles>COc1ccc(-c2c(/C=C/Br)nc(/C=C/Br)n2C)cc1</smiles>

Interestingly, under acidic conditions the formation of the 2-alkyimidazole 4 was not observed in the crude reaction mixture, proving that propionic acid as solvent cleanly increases the regioselectivity of the carbopalladation step of the mechanistic pathway (see later).

With the aim of evaluating the influence of the carboxylic acid, we then carried out the $\mathrm{Ag}(\mathrm{I})$-promoted coupling using acetic acid and pivalic acid as the reaction solvent (entries 2 and 3, Table 1). However, both the acidic solvents revealed less effectiveness in promoting the alkenylation when compared with propionic acid, scoring 24 and 23\% GLC yields, respectively. As recently reported [40], the efficiency of C-H activation reactions carried out using palladium catalysts with carboxylate ligands strictly depends on the $\mathrm{pKa}$ of the carboxylic acid used as the solvent. It is in fact necessary to find a balance between the generation of an active catalyst and the N-3 protonation of the imidazole nucleus with its consequent deactivation. In our case, the pKa of propionic acid (4.87) is intermediate between that of pivalic acid (5.05) and acetic acid (4.76), which means that acetic acid gave a higher percentage of unreactive imidazolium salt, while pivalic acid is not enough acid to generate an active catalyst.

Notably, while the use of silver(I) salts different from AgOAc gave GLC yields ranging from 32 to $38 \%$ (entries 4-6, Table 1), when the alkenylation was performed in the presence of 3.0 equiv of copper(II) acetate $\left(\mathrm{Cu}(\mathrm{OAc})_{2}\right)$, a relevant increase in the GLC yield of 3a was observed, and the C-2 alkenylated product was isolated in a satisfactory $56 \%$ yield (entry 7 , Table 1). From the crude reaction mixture, we were also able to isolate the side-product $\mathbf{5 a}$ in a $13 \%$ yield. 
Table 1. Screening of the reaction conditions for the palladium-catalyzed dehydrogenative alkenylation of 1-methyl-5 (4-methoxyphenyl)imidazole (1a) with styrene (2a).

$$
\mathbf{1 a}+\mathbf{2 a} \underset{\begin{array}{c}
\text { oxidant, solvent } \\
120^{\circ} \mathrm{C}, 24 \mathrm{~h}
\end{array}}{\stackrel{\text { Pd pre-catalyst }}{\longrightarrow}} \mathbf{3 a}+\mathbf{5 a}
$$

\begin{tabular}{|c|c|c|c|c|c|}
\hline Entry $^{1}$ & Oxidant & Solvent & 1a Conversion (GLC \%) & Yield of $3 a(\%)^{2}$ & 3a:5a Ratio (AP\%) ${ }^{3}$ \\
\hline 1 & $\mathrm{AgOAc}$ & $\mathrm{EtCOOH}$ & 90 & 33 & $68: 32$ \\
\hline 2 & $\mathrm{AgOAc}$ & $\mathrm{AcOH}$ & 69 & 24 & $65: 35$ \\
\hline 3 & $\mathrm{AgOAc}$ & PivOH & 64 & 23 & $60: 40$ \\
\hline 4 & $\mathrm{Ag}_{2} \mathrm{CO}_{3}$ & $\mathrm{EtCOOH}$ & 93 & 32 & 61:39 \\
\hline 5 & $\mathrm{Ag}_{2} \mathrm{O}$ & $\mathrm{EtCOOH}$ & 79 & 38 & $70: 30$ \\
\hline 6 & AgTFA & $\mathrm{EtCOOH}$ & 75 & 35 & $66: 35$ \\
\hline 7 & $\mathrm{Cu}(\mathrm{OAc})_{2}$ & $\mathrm{EtCOOH}$ & $>95$ & $61(56)^{4}$ & $76: 24$ \\
\hline $8^{5}$ & $\mathrm{Cu}(\mathrm{OAc})_{2}$ & $\mathrm{EtCOOH}$ & 81 & 39 & $82: 18$ \\
\hline $9^{6}$ & $\mathrm{Cu}(\mathrm{OAc})_{2}$ & $\mathrm{EtCOOH}$ & $<5$ & traces & - \\
\hline $10^{7}$ & $\mathrm{Cu}(\mathrm{OAc})_{2}$ & $\mathrm{EtCOOH}$ & $<5$ & traces & - \\
\hline 11 & $\mathrm{CuO}$ & $\mathrm{EtCOOH}$ & $>95$ & 31 & $52: 48$ \\
\hline 12 & $\mathrm{CuCl}_{2}$ & $\mathrm{EtCOOH}$ & $<5$ & traces & - \\
\hline 13 & $\mathrm{PhI}(\mathrm{OAc})_{2}$ & $\mathrm{EtCOOH}$ & $<5$ & traces & - \\
\hline 14 & $\mathrm{NMO}$ & $\mathrm{EtCOOH}$ & $<5$ & traces & - \\
\hline $15^{8}$ & $\mathrm{Cu}(\mathrm{OAc})_{2}$ & $\mathrm{EtCOOH}$ & $>95$ & $50(42)$ & $74: 26$ \\
\hline $16^{9}$ & $\mathrm{Cu}(\mathrm{OAc})_{2}$ & $\mathrm{EtCOOH}$ & 94 & 37 & $69: 31$ \\
\hline 17 & $\mathrm{Cu}(\mathrm{OAc})_{2}$ & $\mathrm{EtCOOH} / \mathrm{DMF}$ & 91 & 44 & 61:39 \\
\hline 18 & $\mathrm{Cu}(\mathrm{OAc})_{2}$ & $\mathrm{EtCOOH} / \mathrm{NMP}$ & 94 & 45 & $56: 44$ \\
\hline
\end{tabular}

${ }^{1}$ Reaction conditions: 1a $(0.5 \mathrm{mmol}), \mathbf{2 a}(1.0 \mathrm{mmol}), \mathrm{Pd}(\mathrm{OAc})_{2}(0.025 \mathrm{mmol})$, oxidant $(1.5 \mathrm{mmol})$, solvent $(5.0 \mathrm{~mL})$ for $24 \mathrm{~h}$ at $120^{\circ} \mathrm{C}(\mathrm{oil}$ bath temperature) under an argon atmosphere, unless otherwise reported. ${ }^{2}$ GLC yield vs. $\mathrm{PPh}_{3}$. In parentheses isolated yield. ${ }^{3} \mathrm{AP} \%$ is the area percent of the products in the GLC chromatogram. AP\% values are uncorrected for the differences in GLC response factors. ${ }^{4}$ Compound 5a was also isolated in $13 \%$ yield. ${ }^{5}$ This reaction was carried out using $0.5 \mathrm{mmol}$ of $2 \mathbf{a}$. ${ }^{6}$ This reaction was performed at $80{ }^{\circ} \mathrm{C}$ (oil bath temperature). ${ }^{7}$ This reaction was carried out under a dioxygen atmosphere. ${ }^{8}$ This reaction was carried out using $\mathrm{PdCl}_{2}(0.025$ $\mathrm{mmol})$ as pre-catalyst. ${ }^{9}$ This reaction was carried out using $\operatorname{Pd}(\text { acac })_{2}(0.025 \mathrm{mmol})$ as pre-catalyst.

In an attempt to reduce the amount of undesired double alkenylated imidazole $5 \mathbf{a}$, we lowered the amount of styrene to 1.0 equiv, but a parallel lowering of the 3a yield without a significant increase in the selectivity was observed (entry 8 , Table 1 ).

Lowering the reaction temperature from $120^{\circ} \mathrm{C}$ to $80^{\circ} \mathrm{C}$ led to a complete recovery of the reactants (entry 9, Table 1), and a similar negative result was observed when the coupling was performed under a dioxygen atmosphere (entry 10, Table 1).

None of the other typical copper(II) salts tested gave results comparable with that obtained when $\mathrm{Cu}(\mathrm{OAc})_{2}$ was used. CuO gave $3 \mathbf{a}$ in $31 \%$ GLC yield (entry 11, Table 1), while no reaction was observed when $\mathrm{CuCl}_{2}$ was employed as the oxidant (entry 12, Table 1). The use of two typical organic oxidants, i.e., $\mathrm{NMO}$ and $\mathrm{PhI}(\mathrm{OAc})_{2}$ gave unsatisfactory results (entries 13 and 14, Table 1).

As regards the palladium pre-catalyst, replacing $\mathrm{Pd}(\mathrm{OAc})_{2}$ with $\mathrm{PdCl}_{2}$ gave $3 \mathbf{a}$ in a 50\% GLC yield (entry 15, Table 1), while a lower 37\% GLC yield was obtained when $\operatorname{Pd}(\text { acac })_{2}$ was employed (entry 16, Table 1 ).

In order to reduce the amount of propionic acid, we tried also the alkenylation involving 1a and 2a using 1:1 (v:v) mixtures of propionic acid with, respectively, DMF or NMP (entries 17-18, Table 1), but the presence of an organic solvent depletes the formation of the required alkenylimidazole $3 \mathbf{a}$.

\subsection{Scope of the Pd-Catalyzed Dehydrogenative Alkenylation of Imidazoles and Related Azoles}

Considering the results of the preliminary screening, the scope and limitations of this regioselective $\mathrm{C}-2$ dehydrogenative alkenylation under the experimental conditions of entry 7, Table 1, were then evaluated by us. Hence, 5-aryl-1-methylimidazoles $\mathbf{1 a}-\mathbf{f}$ and styrenes $\mathbf{2 a}-\mathbf{g}$ (Figure 1) were reacted in the presence of $5 \mathrm{~mol} \% \mathrm{Pd}(\mathrm{OAc})_{2}$ and 3.0 equiv of $\mathrm{Cu}(\mathrm{OAc})_{2}$ in $\mathrm{EtCOOH}$ at $120^{\circ} \mathrm{C}$ (Table 2$)$. 


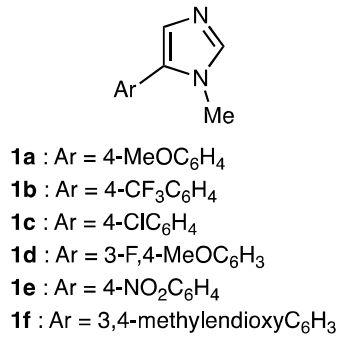<smiles>[X]c1ccccc1[X]</smiles>

$6: \mathrm{X}=\mathrm{NMe}$

$7: X=\mathrm{NH}$

$10: X=O$

2b: $\mathrm{Ar}^{1}=4-\mathrm{MeOC}_{6} \mathrm{H}_{4}$

2c: $\mathrm{Ar}^{1}=4-\mathrm{CF}_{3} \mathrm{C}_{6} \mathrm{H}_{4}$

2d: $\mathrm{Ar}^{1}=4-\mathrm{MeC}_{6} \mathrm{H}_{4}$

2e : $\mathrm{Ar}^{1}=6$-methoxy-napth-2-yl

2f : 3-pyridyl

2g: $4-\mathrm{NO}_{2} \mathrm{C}_{6} \mathrm{H}_{4}$<smiles>Pn1cnc(-c2ccccc2)c1-c1ccccc1</smiles>

$12: \mathrm{R}=\mathrm{Me}$

$14: \mathrm{R}=\mathrm{H}$

Figure 1. Chemical structures of imidazole derivatives 1a-f, 6, 7, 10, 12, 14, and of styrenes 2a-g.

Table 2. Pd-catalyzed, $\mathrm{Cu}(\mathrm{II})$-promoted synthesis of 2-alkenyl-5-aryl-1-methylimidazoles 3a-r by intermolecular dehydrogenative alkenylation of imidazoles $\mathbf{1 a}-\mathbf{f}$ with styrenes $\mathbf{2 a - g}$.

\begin{tabular}{|c|c|c|c|c|c|}
\hline Entry $^{1}$ & Product 3 & Ar & $\mathrm{Ar}^{1}$ & Yield of $3(\%)^{2,3}$ & 3:5 Ratio (AP\%) ${ }^{4}$ \\
\hline 1 & $\mathrm{a}$ & $4-\mathrm{MeOC}_{6} \mathrm{H}_{4}$ & $\mathrm{C}_{6} \mathrm{H}_{5}$ & 56 & $76: 24$ \\
\hline 2 & $\mathrm{~b}$ & $4-\mathrm{MeOC}_{6} \mathrm{H}_{4}$ & $4-\mathrm{MeOC}_{6} \mathrm{H}_{4}$ & 41 & $77: 23$ \\
\hline 3 & c & $4-\mathrm{MeOC}_{6} \mathrm{H}_{4}$ & $4-\mathrm{CF}_{3} \mathrm{C}_{6} \mathrm{H}_{4}$ & 61 & $85: 15$ \\
\hline 4 & $\mathrm{~d}$ & $4-\mathrm{MeOC}_{6} \mathrm{H}_{4}$ & $4-\mathrm{MeC}_{6} \mathrm{H}_{4}$ & 49 & $79: 21$ \\
\hline 5 & $\mathrm{e}$ & $4-\mathrm{MeOC}_{6} \mathrm{H}_{4}$ & 6-MeO-naphth-2-yl & 51 & $77: 23$ \\
\hline 6 & $\mathrm{f}$ & $4-\mathrm{MeOC}_{6} \mathrm{H}_{4}$ & $4-\mathrm{NO}_{2} \mathrm{C}_{6} \mathrm{H}_{4}$ & 44 & $82: 18$ \\
\hline 7 & $\mathrm{~g}$ & $4-\mathrm{CF}_{3} \mathrm{C}_{6} \mathrm{H}_{4}$ & $\mathrm{C}_{6} \mathrm{H}_{5}$ & 43 & $78: 22$ \\
\hline 8 & $\mathrm{~h}$ & $4-\mathrm{CF}_{3} \mathrm{C}_{6} \mathrm{H}_{4}$ & $4-\mathrm{MeOC}_{6} \mathrm{H}_{4}$ & 41 & $75: 25$ \\
\hline 9 & $\mathrm{i}$ & $4-\mathrm{CF}_{3} \mathrm{C}_{6} \mathrm{H}_{4}$ & $4-\mathrm{MeC}_{6} \mathrm{H}_{4}$ & 44 & $75: 25$ \\
\hline 10 & $\mathrm{j}$ & $4-\mathrm{CF}_{3} \mathrm{C}_{6} \mathrm{H}_{4}$ & $4-\mathrm{CF}_{3} \mathrm{C}_{6} \mathrm{H}_{4}$ & 50 & $79: 21$ \\
\hline 11 & $\mathrm{k}$ & $4-\mathrm{ClC}_{6} \mathrm{H}_{4}$ & $\mathrm{C}_{6} \mathrm{H}_{5}$ & 45 & $78: 22$ \\
\hline 12 & 1 & $4-\mathrm{ClC}_{6} \mathrm{H}_{4}$ & $4-\mathrm{MeOC}_{6} \mathrm{H}_{4}$ & $28^{5}$ & nd \\
\hline 13 & $\mathrm{~m}$ & $4-\mathrm{ClC}_{6} \mathrm{H}_{4}$ & $4-\mathrm{CF}_{3} \mathrm{C}_{6} \mathrm{H}_{4}$ & 46 & $93: 7$ \\
\hline 14 & $\mathrm{n}$ & $4-\mathrm{ClC}_{6} \mathrm{H}_{4}$ & 4-pyridyl & $16^{6,7}$ & nd \\
\hline 15 & $\mathrm{o}$ & $4-\mathrm{ClC}_{6} \mathrm{H}_{4}$ & $4-\mathrm{NO}_{2} \mathrm{C}_{6} \mathrm{H}_{4}$ & $27^{6,8}$ & nd \\
\hline 16 & $\mathrm{p}$ & $3-\mathrm{F}, 4-\mathrm{MeOC}_{6} \mathrm{H}_{3}$ & $4-\mathrm{MeOC}_{6} \mathrm{H}_{4}$ & 56 & $78: 22$ \\
\hline 17 & $\mathrm{q}$ & $4-\mathrm{NO}_{2} \mathrm{C}_{6} \mathrm{H}_{4}$ & $4-\mathrm{MeOC}_{6} \mathrm{H}_{4}$ & $30^{9}$ & nd \\
\hline 18 & $\mathrm{r}$ & 3,4-Methylendioxy $\mathrm{C}_{6} \mathrm{H}_{3}$ & $4-\mathrm{MeOC}_{6} \mathrm{H}_{4}$ & 52 & $76: 24$ \\
\hline
\end{tabular}

${ }^{1}$ Reaction conditions: $1(0.5 \mathrm{mmol}), 2(1.0 \mathrm{mmol}), \mathrm{Pd}(\mathrm{OAc})_{2}(0.025 \mathrm{mmol}), \mathrm{Cu}(\mathrm{OAc})_{2}(1.5 \mathrm{mmol}), \mathrm{EtCOOH}(5.0 \mathrm{~mL})$ for $24 \mathrm{~h}$ at $120^{\circ} \mathrm{C}$ (oil bath temperature) under an argon atmosphere, unless otherwise reported. ${ }^{2}$ Isolated yield. ${ }^{3}$ After $24 \mathrm{~h}$ the GLC conversion of 1 was $>95 \%$ unless otherwise noted. ${ }^{4} \mathrm{AP} \%$ is the area percent of the products in the GLC chromatogram. AP\% values are uncorrected for the differences in GLC response factors. ${ }^{5}$ The GLC conversion of $1 \mathrm{c}$ was $49 \% .{ }^{6}$ The coupling was carried out for $72 \mathrm{~h} .{ }^{7}$ The GLC conversion of $1 \mathrm{c}$ was $45 \% .{ }^{8}$ The GLC conversion of $1 \mathrm{c}$ was $56 \% .{ }^{9}$ The GLC conversion of $1 \mathbf{e}$ was $53 \%$.

As summarized in Table 2, all the 5-arylimidazoles 1a-f gave the required 2-alkenyl substituted analogues in moderate to good yields. In details, 5-arylimidazoles 1a, 1d, and $\mathbf{1 f}$, bearing electron-rich aryl rings at their 5-position gave slightly better results, giving the alkenylated products $\mathbf{3 a}-\mathbf{f}, \mathbf{3 p}$ and $\mathbf{3 r}$ in $41-61 \%$ isolated yield (entries $1-6,16$, and 18 , Table 2). In contrast, 5-(4-trifluoromethylphenyl) imidazole 1b, 5-(4-chlorophenyl)imidazole 1c, and 5-(4-nitrophenyl)imidazole 1e gave lower yields and sometimes incomplete GLC

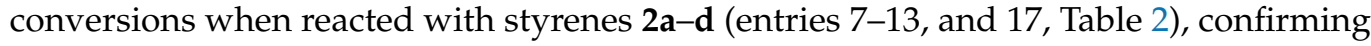
that the efficiency of this dehydrogenative coupling is related to the electronic nature of the C-5 aromatic substituent.

That electron-poor substituents negatively influence the coupling is evidenced also when styrenes $\mathbf{2} \mathbf{f}$ and $\mathbf{2} \mathbf{g}$ were employed as reaction partners, and it seems synergic with the effect exerted by electron-withdrawing groups at C-5 on the imidazole counterpart. Actually, while an acceptable $44 \%$ isolate yield was observed when imidazole 1a was reacted with 4-nitrostyrene $\mathbf{2 g}$ (entry 6 , Table 2), a more significant reduction in the chemical 
yield was recorded when the 4-chlorophenyl substituted imidazole 1c reacted with the electron-poor styrenes $\mathbf{2 f}$ and $\mathbf{2 g}$ (entries 14 and 15, Table 2).

Regarding the results summarized in Table 2, it is also important to note that the efficiency of the coupling strongly depends also on the relative stability of the substituted styrenes $\mathbf{2}$ in the acid medium. It is in fact well known that electron-rich styrenes, such as 4 -methoxystyrene $\mathbf{2 b}$, are highly susceptible to polymerization in an acidic environment, while electron-poor analogues such as 4-nitrostyrene $\mathbf{2 g}$ are almost inert under the same conditions [41]. For this reason, it is not possible to make a clear correlation between the nature of the coupling partners $\mathbf{1}$ and $\mathbf{2}$ and the observed isolated yields of compounds 3 .

We were pleased to find that the reaction conditions summarized in Table 1, entry 7, are also well suited for the $\mathrm{C}-2$ dehydrogenative alkenylation of 1-methyl-1H-benzimidazole (6) and $1 \mathrm{H}$-benzimidazole (7). As summarized in Scheme 5, 1-methyl-2-styrylbenzimidazole 8 and 2-styrylbenzimidazole 9 were isolated in a satisfactory 87 and $64 \%$ yield, respectively. In contrast, the reaction involving benzoxazole 10 with styrene gave the required 2-styrylbenzoxazole $\mathbf{1 1}$ in a lower isolated yield (30\%) (Scheme 5), while no product was observed when benzothiazole was submitted to the dehydrogenative alkenylation (result not shown).
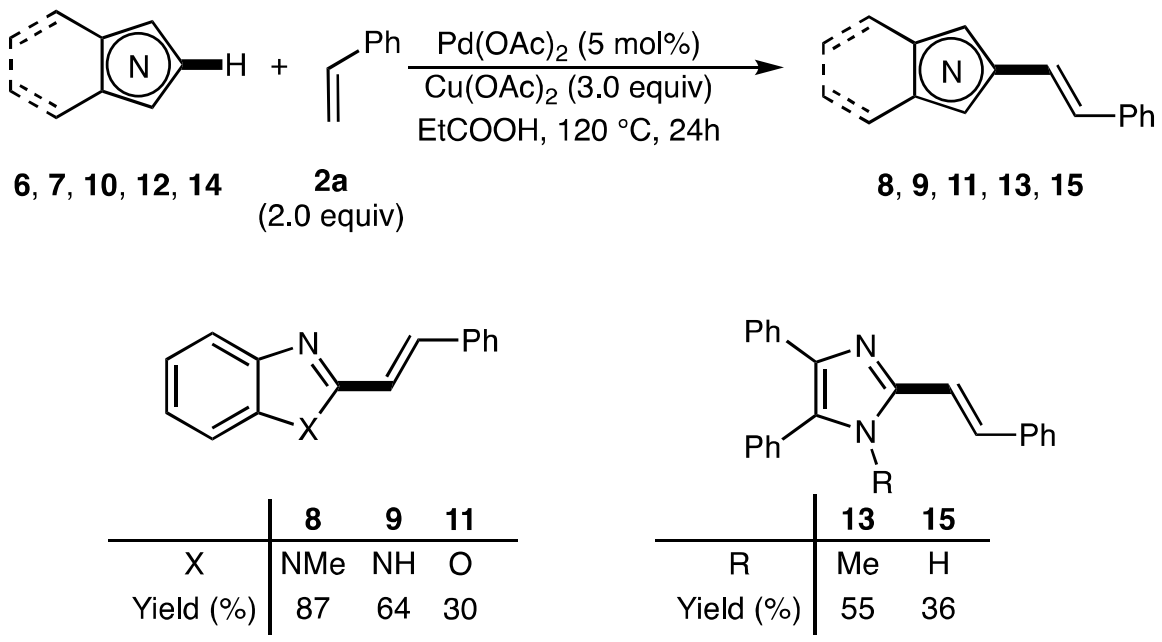

Scheme 5. Pd-catalyzed, $\mathrm{Cu}(\mathrm{II})$-promoted dehydrogenative alkenylation of azoles 6, 7, 10, 12, and 14 with styrene (2a).

A positive result was instead obtained in the C-2 alkenylation of 4,5-diphenyl-1methyl-1H-imidazole (12) with styrene (2a). In fact, the expected 2-styryl-substituted derivative 13 was isolated in a satisfactory 55\% yield (Scheme 5). However, when the coupling was carried out using the analogue $\mathrm{NH}$-free imidazole 14 the expected 4,5diphenyl-2-styrylimidazole 15 was recovered in 36\% isolated yield (Scheme 5).

Considering also that the $\mathrm{C} 4-\mathrm{H}$ bond seems to be reactive when the other two positions on the imidazole ring are occupied due to the formation of side-products 5 , we also tried to force the C-4 alkenylation by using 5-(4-methoxyphenyl)-1,2-dimethyl- $1 \mathrm{H}$-imidazole (16) as a typical 2,5-disubstituted imidazole. Fortunately, when the reaction was carried out using 2-methyl substituted imidazole $\mathbf{1 6}$ and 5.0 equiv of $\mathbf{2 a}$, the expected C4-alkenylated imidazole 17 was recovered in a 50\% isolated yield (Scheme 6). 


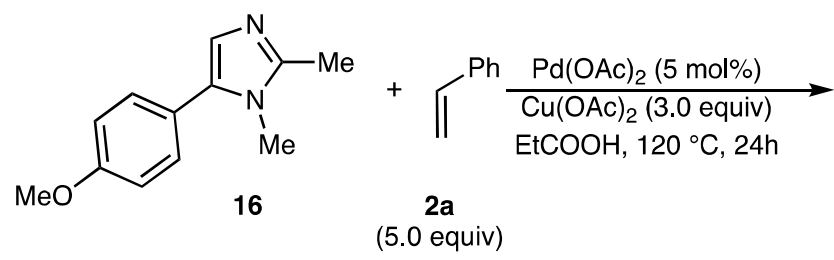<smiles>[3H]C([18OH])([18OH])n1c(C)nc(/C=C/c2ccccc2)c1-c1ccc(OC)cc1</smiles>

Scheme 6. Pd-catalyzed, $\mathrm{Cu}(\mathrm{II})$-promoted dehydrogenative alkenylation of 5-(4-methoxyphenyl)-1,2dimethyl-1H-imidazole (16) with styrene (2a).

With the intention of verifying the regioselectivity of our new Pd/Cu-mediated dehydrogenative alkenylation protocol, we set up a model reaction involving 1-methylimidazole 18 and styrene (2a) the experimental conditions of entry 7, Table 1 . Hence, 18 and 2.0 equiv of $2 \mathbf{a}$ were reacted in the presence of $5 \mathrm{~mol} \% \mathrm{Pd}(\mathrm{OAc})_{2}$ and 3.0 equiv of $\mathrm{Cu}(\mathrm{OAc})_{2}$ in EtCOOH (Method A, Scheme 7). To our delight, after stirring at $120^{\circ} \mathrm{C}$ for $24 \mathrm{~h}$, the GLC conversion of 18 was $83 \%$, and we were able to isolate $(E)$-1-methyl-2-styryl- $1 H$-imidazole (19) in $45 \%$ yield confirming the expected C-2 selectivity.

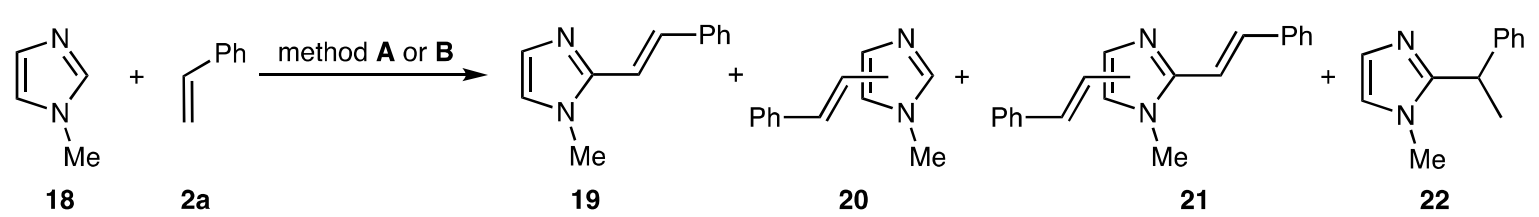

Method A : 2a (2.0 equiv), $\mathrm{Pd}(\mathrm{OAc})_{2}(5 \mathrm{~mol} \%), \mathrm{Cu}(\mathrm{OAc})_{2}$ (3.0 equiv), $\mathrm{EtCOOH}, 120{ }^{\circ} \mathrm{C}, 24 \mathrm{~h}$, air $(45 \%)$

Method B : 2a (2.5 equiv), Pd(TFA) 2 (5 mol\%), AgTFA (1.0 equiv), 1,10-Phen (7.5 mol\%), toluene, $130{ }^{\circ} \mathrm{C}, 16 \mathrm{~h}$ in a closed vessel under $\mathrm{Ar}(33 \%)$

\begin{tabular}{ccccc} 
& \multicolumn{4}{c}{ AP GLC\% } \\
\cline { 2 - 5 } Compound & $\mathbf{1 9}$ & $\mathbf{2 0}$ & $\mathbf{2 1}$ & $\mathbf{2 2}$ \\
\hline Method A & 93 & 3 & 4 & 0 \\
Method B & 73 & 6 & 4 & 17
\end{tabular}

Scheme 7. Pd-catalyzed dehydrogenative alkenylation of 1-methyl-1H-imidazole (18) with styrene (2a) according to our new protocol (Method A), or to Ong procedure (Method B) [37].

In contrast, when the same coupling was carried out using the Ong protocol [37], i.e., reacting $\mathbf{1 6}$ and 2.5 equiv of $2 \mathbf{a}$ in a closed vessel for $16 \mathrm{~h}$ at $130{ }^{\circ} \mathrm{C}$ in toluene in the presence of $10 \mathrm{~mol} \% \mathrm{Pd}(\mathrm{TFA})_{2}, 15 \mathrm{~mol} \%$ 1,10-Phen and 2.0 equiv AgTFA, the GLC conversion of $\mathbf{1 6}$ was lower $(70 \%)$, and the required imidazole 19 was observed in only $33 \%$ isolated yield (vs. a reported 67\% yield [37]) (Method B, Scheme 7). It is worth mentioning that also in this case GLC-MS analysis of the crude reaction mixture evidences the presence of the side-product 22, a structural analogue to imidazole 4 already observed when the same reaction was performed with 1-methylbenzimidazole 1a (Scheme 4), in a 77:23 GLC ratio with 19.

As already noted for $\mathrm{Pd} / \mathrm{Cu}$-mediated direct arylation reactions of 1,3-azoles with aryl halides [44-46], it is thought that an initial N-3 protonation or complexation with copper enhances the acidity of the $\mathrm{C} 2-\mathrm{H}$ bond, allowing a fast and regioselective palladation to give the imidazole intermediate $\mathbf{A}$. The subsequent regioselective carbopalladation yields the intermediate $\mathbf{B}$, which decomposes through $\beta$-elimination to generate the desired product 3 and $\operatorname{Pd}(0)$. Finally, the reoxidation of $\mathrm{Pd}(0)$ to $\mathrm{Pd}(\mathrm{II})$ by $\mathrm{Cu}(\mathrm{II})$ closed the catalytic cycle.

Based on previous reports $[2,11,13,42,43]$ and according to the results described here, a plausible reaction mechanism is summarized in Figure 2. 


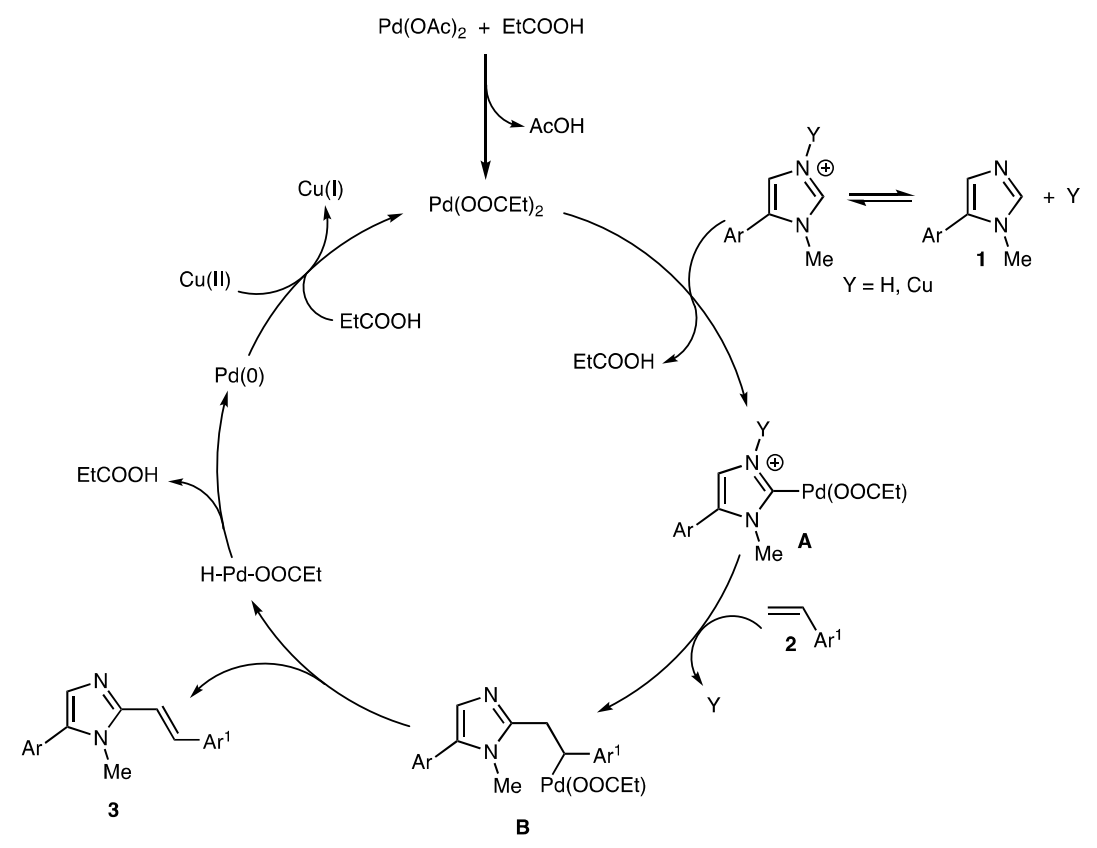

Figure 2. Suggested mechanistic pathway for the Pd/Cu-mediated dehydrogenative alkenylation of imidazoles.

\section{Materials and Methods}

Melting points were recorded on a hot-stage microscope (Reichert Thermovar). Precoated silica gel PET foils (Sigma-Aldrich, St. Louis, MO, USA) were used for TLC analyses. GLC analyses were performed on a Dani GC 1000 instrument equipped with a PTV injector and recorded with a Dani DDS 1000 data station. Three types of capillary columns were used: an Agilent J\&W HP-5 ms column $(30 \mathrm{~m} \times 0.25 \mathrm{~mm}$ i.d. $\times 0.25 \mu \mathrm{m})$, an Agilent J\&W DB-5 column $(30 \mathrm{~m} \times 0.25 \mathrm{~mm}$ i.d. $\times 1 \mu \mathrm{m})$ and an Altech AT-35 FSOT column $(30 \mathrm{~m} \times 0.25 \mathrm{~mm}$ i.d. $\times 0.25 \mu \mathrm{m})$. EI-MS spectra were recorded at $70 \mathrm{eV}$ by GLC-MS, performed on an Agilent 6890N gas-chromatograph interfaced with an Agilent 5973N mass detector. The ESI spectra were acquired on an Acquity QDa Water spectrometer (Temperature Probe: $600{ }^{\circ} \mathrm{C}$; ESI capillary voltage $1.5 \mathrm{~V}$; Cone voltage $15 \mathrm{~V}$; mass range 200-1000) coupled with an Acquity HUPLC Water (Phase A 95/5 $\mathrm{H}_{2} \mathrm{O} / \mathrm{ACN}+0.1 \%$ Formic Acid, Phase B 5/95 H $\mathrm{H}_{2} \mathrm{O} / \mathrm{ACN}+0.1 \%$ Formic Acid; Column Acquity UPLC $2.1 \times 100 \mathrm{~mm}$, BEH $\mathrm{C} 18,1.7 \mu \mathrm{m}$; Flow $0.6 \mathrm{~mL} / \mathrm{min})$. Elementar analyses were acquired with an Elementar Vario Micro Cube in CHNS mode. ${ }^{1} \mathrm{H}$ NMR spectra were recorded on a Varian Gemini 200 or on a Bruker $400 \mathrm{MHz}$ spectrometer using TMS as an internal standard. The following notation was used in order to report NMR spectra: $\mathrm{s}=$ singlet, $\mathrm{bs}=$ broad singlet, $\mathrm{d}=$ doublet, $\mathrm{dd}=$ double doublet $\mathrm{t}=$ triplet, $\mathrm{dt}=$ double triplet $\mathrm{q}=$ quadruplet The ${ }^{13} \mathrm{C}$ NMR spectra were recorded at 50 or $100 \mathrm{MHz}$, using Varian Gemini or Bruker instrument respectively, and the spectra were referred to as the signal of the solvent. Copies of ${ }^{1} \mathrm{H}$ and ${ }^{13} \mathrm{C}$ NMR spectra of all the new compounds are provided as Supplementary Materials. Unless otherwise stated all the reactions were performed under a positive atmosphere of argon by standard syringe, cannula and septa techniques. All the liquid styrenes $\mathbf{2} \mathbf{a}-\mathbf{d}, \mathbf{f}$ were purified by distillation at reduced pressure over $\mathrm{CaH}_{2}$. Propionic acid was distilled at atmospheric pressure. 5-(4-Methoxyphenyl)-1-methyl-1Himidazole (1a), 1-methyl-5-(4-(trifluoromethyl)phenyl)-1H-imidazole (1b) 1-methyl-5-(4chlorophenyl)-1 $H$-imidazole (1c), 5-(3-fluoro-4-methoxyphenyl)-1-methyl-1H-imidazole (1d), 5-(4-nitrophenyl)-1-methyl-1H-imidazole (1e), 5-(benzo[d][1,3]dioxol-5-yl)-1-methyl$1 \mathrm{H}$-imidazole (1f) were synthesized according to literature procedure previously developed by us [47]. The following compounds were prepared according to reported procedures: 1-Methyl-4,5-diphenyl-1H-imidazole (12) (yield: 80\%) [48], 5-(4-methoxyphenyl)-1,2- 
dimethyl-1H-imidazole (16) (yield: 66\%) [49], 1-nitro-4-vinylbenzene (2g) (yield: 61\%) [50]. All the other commercially available reagents and solvents were used as received.

3.1. (E)-5-(4-Methoxyphenyl)-1-methyl-2-styryl-1H-imidazole (3a) and

5-(4-methoxyphenyl)-1-methyl-2-(1-phenylethyl)-1H-imidazole (4)

As summarized in Scheme 4, a mixture of 5-(4-methoxyphenyl)-1-methyl-1H-imidazole (1a) $(94.0 \mathrm{mg}, 0.5 \mathrm{mmol})$, styrene (2a) $(0.14 \mathrm{~mL}, 130 \mathrm{mg}, 1.25 \mathrm{mmol}), \mathrm{Pd}(\mathrm{TFA})_{2},(16.6 \mathrm{mg}$, $0.05 \mathrm{mmol}), 1,10$-phenantroline (13.5 mg, $0.075 \mathrm{mmol})$, and AgTFA (27.3 mg $1.0 \mathrm{mmol}$ ) in toluene $(2 \mathrm{~mL})$ was stirred in a Paar Microwave $50^{\circledR}$ reactor for $16 \mathrm{~h}$ at $130^{\circ} \mathrm{C}$. After cooling to room temperature, the mixture was diluted with AcOEt $(20 \mathrm{~mL})$ then filtered on celite and the filter was washed with $15 \mathrm{~mL} \mathrm{AcOEt}$ and $20 \mathrm{~mL} \mathrm{CH} \mathrm{Cl}_{2}$. The crude reaction mixture was concentrated under reduced pressure and the residue was purified by flash chromatography on silica gel with a mixture of toluene and AcOEt (50:50) as eluent. Concentration of the first eluted chromatographic fractions allowed the isolation of compound 3a (34.8 mg, $24 \%$ ) light-pink solid: m.p. $150-152{ }^{\circ} \mathrm{C} .{ }^{1} \mathrm{H}$ NMR $(400 \mathrm{MHz}$, $\left.\mathrm{CDCl}_{3}\right): \delta 7.63(\mathrm{~d}, 1 \mathrm{H}, J=15.85 \mathrm{~Hz}), 7.54(\mathrm{~d}, 2 \mathrm{H}, J=7.54), 7.40-7.22(\mathrm{~m}, 5 \mathrm{H}), 7.09(\mathrm{~s}, 1 \mathrm{H})$, 7.00-6.92 (m, 3H), $3.84(\mathrm{~s}, 3 \mathrm{H}), 3.64(\mathrm{~s}, 3 \mathrm{H}) .{ }^{13} \mathrm{C}$ NMR $\left(100 \mathrm{MHz}, \mathrm{CDCl}_{3}\right): \delta 159.39,146.26$, $136.69,134.34,132.12,130.06(2 \mathrm{C}), 128.68(2 \mathrm{C}), 128.07,127.49,126.66(2 \mathrm{C}), 122.23,114.15(2 \mathrm{C})$, 113.86, 55.24, 30.95. EI-MS $m / z$ (\%): 290 (31), 289 (100), 274 (6), 245 (10), 144 (5). $\mathrm{C}_{19} \mathrm{H}_{18} \mathrm{~N}_{2} \mathrm{O}$ (290.37): calcd. C, 78.59; H, 6.25; N, 9.65; found C 78.64, H 6.26, N 9.67.

Concentration of the last eluted chromatographic fractions with AcOEt allowed the isolation of compound $4\left(17.5 \mathrm{mg}, 12 \%\right.$ yield) as a light orange oil. ${ }^{1} \mathrm{H} \mathrm{NMR}(400 \mathrm{MHz}$, $\left.\mathrm{CDCl}_{3}\right): \delta 7.35-7.27(\mathrm{~m}, 3 \mathrm{H}), 7.26-7.18(\mathrm{~m}, 4 \mathrm{H}), 7.02(\mathrm{~s}, 1 \mathrm{H}), 6.95-6.90(\mathrm{~m}, 2 \mathrm{H}), 4.16(\mathrm{q}, 1 \mathrm{H}$, $J=7 \mathrm{~Hz}), 3.82(\mathrm{~s}, 3 \mathrm{H}), 3.26(\mathrm{~s}, 3 \mathrm{H}), 1.77(\mathrm{~d}, 3 \mathrm{H}, J=7 \mathrm{~Hz}) .{ }^{13} \mathrm{C}$ NMR $\left(100 \mathrm{MHz}, \mathrm{CDCl}_{3}\right)$ : $\delta$ 159.30, 150.65, 143.87, 133.72, 130.24 (2C), 128.80 (2C), 127.30 (2C), 126.59, 125.50, 122.83, 114.07 (2C), 55.33, 38.91, 30.91, 21.86. EI-MS $m / z$ (\%): 292 (100), 277 (90), 262 (10), 233 (20), 215 (12), 201 (40). $\mathrm{C}_{19} \mathrm{H}_{20} \mathrm{~N}_{2} \mathrm{O}$ (292.38): calcd. C, 78.05; H, 6.90; N, 9.58; found C 77.98, H 6.89, N 9.56.

Compound 3a was also obtained in a $56 \%$ isolated yield from the $\mathrm{Pd}(\mathrm{OAc})_{2}$-catalyzed reactions of $\mathbf{1 a}$ and $\mathbf{2 a}$ carried out using $\mathrm{Ag}_{2} \mathrm{O}, \mathrm{AgTFA}$, or $\mathrm{Cu}(\mathrm{OAc})_{2}$ as oxidant (entry 7 , Table 1 ), and in $42 \%$ isolated yield when the alkenylation was performed using $\mathrm{PdCl}_{2} / \mathrm{Cu}(\mathrm{OAc})_{2}$ as pre-catalyst/oxidant (entry 15, Table 1 ).

3.2. Procedure for the Screening of the Reaction Conditions for the Pd-Catalyzed Dehydrogenative C2-Alkenylation of 5-(4-Methoxyphenyl)-1-Methyl-1H-Imidazole (1a) with Styrene (2a) Using Carboxylic Acids as Reaction Solvents

A mixture of 5-(4-methoxyphenyl)-1-methyl-1H-imidazole (1a) $(94 \mathrm{mg}, 0.5 \mathrm{mmol})$, styrene (2a) $(0.12 \mathrm{~mL}, 104 \mathrm{mg}, 1.0 \mathrm{mmol})$, palladium pre-catalyst $(0.025 \mathrm{mmol})$, oxidant $(1.5 \mathrm{mmol})$, in the selected solvent $(5 \mathrm{~mL})$ was stirred for $24 \mathrm{~h}$ at $120^{\circ} \mathrm{C}$. After cooling to room temperature, when an $\mathrm{Ag}(\mathrm{I})$ oxidant was used the crude reaction mixture was diluted with AcOEt, and $\mathrm{PPh}_{3}$ was added as internal standard. When a $\mathrm{Cu}$ (II) salt was used as oxidant, the crude reaction mixture was diluted with AcOEt and poured into a saturated aqueous $\mathrm{NH}_{4} \mathrm{Cl}$ solution. The resulting mixture was basified with a few drops of aqueous $\mathrm{NH}_{4} \mathrm{OH}$, stirred in the open air for $0.5 \mathrm{~h}$, and then extracted with $\mathrm{AcOEt}$ and with $\mathrm{CH}_{2} \mathrm{Cl}_{2}$. The organic extract was washed with water, dried, filtered, and $\mathrm{PPh}_{3}$ was added as internal standard.

All the resulting mixtures were analyzed by GLC, GC-MS, and UPLC-MS. Table 1 summarizes the results of this screening.

(E)-5-(4-methoxyphenyl)-1-methyl-2-styryl-1H-imidazole (3a) and 5-(4-methoxyphenyl)-1-methyl-2,4-di((E)-styryl)-1H-imidazole (5a)

The crude reaction mixture (entry 7 , Table 1 ) was concentrated at reduced pressure and the residue was purified by flash chromatography on silica gel with a mixture of toluene and AcOEt (90:10) as eluent. Concentration of the first eluted chromatographic fractions allowed the isolation of compound $\mathbf{5 a}(25.5 \mathrm{mg}, 13 \%)$ as a yellow solid: m.p $57-58{ }^{\circ} \mathrm{C} .{ }^{1} \mathrm{H}$ NMR $(400$ 
$\left.\mathrm{MHz}, \mathrm{CDCl}_{3}\right): \delta 7.75(\mathrm{~d}, J=15.8 \mathrm{~Hz}, 1 \mathrm{H}), 7.59-7.57(\mathrm{~m}, 2 \mathrm{H}), 7.47-7.43(\mathrm{~m}, 2 \mathrm{H}), 7.39-7.36$ $(\mathrm{m}, 2 \mathrm{H}), 7.31-7.24(\mathrm{~m}, 5 \mathrm{H}), 7.18-7.15(\mathrm{~m}, 2 \mathrm{H}), 7.04-7.03(\mathrm{~m}, 2 \mathrm{H}), 6.98(\mathrm{~d}, J=15.8 \mathrm{~Hz}, 1 \mathrm{H})$, $6.89(\mathrm{~d}, J=15.8 \mathrm{~Hz}, 1 \mathrm{H}), 3.90(\mathrm{~s}, 3 \mathrm{H}), 3.55$ (s, 3H). ${ }^{13} \mathrm{CNMR}\left(100 \mathrm{MHz}, \mathrm{CDCl}_{3}\right): \delta 159.8$, $145.9,138.2,137.2,136.8,133.3,132.5,131.9$ (2C), 128.8 (2C), 128.5 (2C), 128.3, 127.2, 126.9 (2C), 126.8, 126.3 (2C), 121.6, 119.6, 114.4 (2C), 113.7, 55.4, 31.1. EI-MS m/z (\%): 392 (90), 391 (100), 207 (6), 157 (10), 144 (13) 115 (6). $\mathrm{C}_{27} \mathrm{H}_{24} \mathrm{~N}_{2} \mathrm{O}$ (262.35): calcd. C, 82.62; H, 6.16; N, 7.14; found C 82.57, H 6.12, N 7.16.

The concentration of the last fractions, eluted with a mixture of toluene and AcOEt (50:50) allowed the isolation of compound 3a $(81.1 \mathrm{mg}, 56 \%)$ as a light-pink solid, m.p. $151-152{ }^{\circ} \mathrm{C}$. The physical and spectral properties of this compound are in agreement with those reported in Section 3.1.

\subsection{General Procedure for the Pd(II)/Cu(II)-Promoted Dehydrogenative Alkenylation of Azoles} with Styrenes

To a suspension of the appropriate azole $\mathbf{1 a}-\mathbf{f}, \mathbf{6}, \mathbf{7}, \mathbf{1 0}, \mathbf{1 2}$ or $14(0.5 \mathrm{mmol}), \mathrm{Pd}(\mathrm{OAc})_{2}$ $(5.6 \mathrm{mg}, 0.025 \mathrm{mmol}), \mathrm{Cu}(\mathrm{OAc})_{2}(272.5 \mathrm{mg}, 1.5 \mathrm{mmol})$ in $\mathrm{EtCOOH}(5 \mathrm{~mL})$, the appropriate styrene $\mathbf{2 a}-\mathbf{g}(1.0 \mathrm{mmol})$ was added under vigorous stirring. The resulting mixture was heated for $24 \mathrm{~h}$ at $120^{\circ} \mathrm{C}$. After cooling to room temperature, the crude reaction mixture was diluted with AcOEt $(50 \mathrm{~mL})$ and sequentially washed with a 2:1 (v:v) solution of saturated aqueous $\mathrm{NH}_{4} \mathrm{Cl}$ and aqueous $\mathrm{NH}_{4} \mathrm{OH}(2 \times 20 \mathrm{~mL}), \mathrm{H}_{2} \mathrm{O}(1 \times 20 \mathrm{~mL})$, and brine $(1 \times 20 \mathrm{~mL})$. The aqueous phase was extracted with $\mathrm{CH}_{2} \mathrm{Cl}_{2}(2 \times 20 \mathrm{~mL})$. The combined organic extracts were washed with water, dried, and concentrated under reduced pressure. The residue was purified by flash chromatography on silica gel. This procedure was used to prepare compounds 3b-r (Table 2), 8, 9, 11, 13, 15 (Scheme 5) and $\mathbf{1 7}$ (Scheme 6).

\subsection{1. (E)-5-(4-Methoxyphenyl)-2-(4-methoxystyryl)-1-methyl-1H-imidazole (3b)}

The crude reaction product, which was obtained by Pd-catalyzed reaction of $1 \mathrm{a}$ with $\mathbf{2 b}$ (entry 2, Table 2), was purified by flash chromatography on silica gel with a mixture of $\mathrm{CH}_{2} \mathrm{Cl}_{2}$ and $\mathrm{MeOH}(97: 3)$ as eluent to give $3 \mathrm{~b}(65.7 \mathrm{mg}, 41 \%)$ as a light-orange solid: m.p. $=173-175^{\circ} \mathrm{C} .{ }^{1} \mathrm{H} \mathrm{NMR}\left(400 \mathrm{MHz} \mathrm{CDCl}_{3}\right): \delta 7.58(\mathrm{~d}, 1 \mathrm{H}, J=15.9 \mathrm{~Hz}), 7.48(\mathrm{~d}, 2 \mathrm{H}, J=8.5$ $\mathrm{Hz}), 7.30(\mathrm{~d}, 2 \mathrm{H}, J=8.7), 7.07(\mathrm{~s}, 1 \mathrm{H}), 6.97(\mathrm{~d}, 2 \mathrm{H}, J=8.6 \mathrm{~Hz}), 6.90(\mathrm{~d}, 2 \mathrm{H}, J=8.5 \mathrm{~Hz}), 6.82$ $(\mathrm{d}, 1 \mathrm{H}, J=15.9 \mathrm{~Hz}), 3.84(\mathrm{~s}, 3 \mathrm{H}), 3.82(\mathrm{~s}, 3 \mathrm{H}), 3.62(\mathrm{~s}, 3 \mathrm{H}) .{ }^{13} \mathrm{C} \mathrm{NMR}\left(100 \mathrm{MHz}, \mathrm{CDCl}_{3}\right)$ : $\delta 159.87,159.54,146.81,134.21,132.20,130.27$ (2C), 129.69, 128.17 (2C), 127.45, 122.58, 114.31 (4C), 111.88, 55.46, 55.43, 31.14. EI-MS m/z (\%): 320 (39), 319 (100), 304 (7), 276 (5),160 (5). ESI-MS (+): $m / z(\%)=321(100)[\mathrm{M}+\mathrm{H}]^{+} . \mathrm{C}_{20} \mathrm{H}_{20} \mathrm{~N}_{2} \mathrm{O}_{2}$ (320.39): calcd. C, 74.98; H, 6.29; N, 8.74; found C, 75.05, H, 6.31, N, 8.76.

\subsection{2. (E)-5-(4-Methoxyphenyl)-1-methyl-2-(4-(trifluoromethyl)styryl)-1H-imidazole (3c)}

The crude reaction product, which was obtained by Pd-catalyzed reaction of 1 a with 2c (entry 3, Table 2), was purified by flash chromatography on silica gel with a mixture of toluene and AcOEt (65/35) as eluent to give 3c (109.2 mg, 61\% yield) as yellow solid: m.p. $=174-175^{\circ} \mathrm{C} .{ }^{1} \mathrm{H}$ NMR $\left(400 \mathrm{MHz} \mathrm{CDCl}_{3}\right): \delta 7.60-7.47(\mathrm{~m}, 5 \mathrm{H}), 7.26-7.23(\mathrm{~m}, 2 \mathrm{H})$, $7.05(\mathrm{~s}, 1 \mathrm{H}), 6.97(\mathrm{~d}, 1 \mathrm{H}, J=15.09 \mathrm{~Hz}), 6.94-6.90(\mathrm{~m}, 2 \mathrm{H}), 3.79(\mathrm{~s}, 3 \mathrm{H}), 3.60(\mathrm{~s}, 3 \mathrm{H}) .{ }^{13} \mathrm{C}$ NMR $\left(100 \mathrm{MHz}, \mathrm{CDCl}_{3}\right): \delta 159.77,145.86,140.41,135.05,130.53,130.38(2 \mathrm{C}), 129.80(\mathrm{q}, J=32.4 \mathrm{~Hz})$, $128.18,126.92(2 \mathrm{C}), 125.82(\mathrm{q}, 2 \mathrm{C}, J=3.8 \mathrm{~Hz}), 124.29(\mathrm{q}, J=271.9 \mathrm{~Hz}), 122.26,116.29,114.42$ (2C), 55.51, 31.23. EI-MS $m / z(\%)$ : 358 (30), 357 (100), 342 (5), 313 (10). ESI-MS (+): $m / z(\%)=359(100)[\mathrm{M}+\mathrm{H}]^{+} . \mathrm{C}_{20} \mathrm{H}_{17} \mathrm{~F}_{3} \mathrm{~N}_{2} \mathrm{O}$ (358.36): calcd. C, 67.03; H, 4.78; N, 7.82; found C, 66.97, H, 4.79, N, 7.80.

\subsection{3. (E)-5-(4-Methoxyphenyl)-1-methyl-2-(4-methylstyryl)-1H-imidazole (3d)}

The crude reaction product, which was obtained by Pd-catalyzed reaction of $\mathbf{1 a}$ with 2d (entry 4, Table 2), was purified by flash chromatography on silica gel with a mixture of toluene and AcOEt (20/80) as eluent to give $3 \mathbf{d}(74.5 \mathrm{mg}, 49 \%$ yield) as dark orange solid: m.p. $=124-129^{\circ} \mathrm{C} .{ }^{1} \mathrm{H}$ NMR $\left(400 \mathrm{MHz}, \mathrm{CDCl}_{3}\right): \delta 7.60(\mathrm{~d}, 1 \mathrm{H}, J=15.9 \mathrm{~Hz}), 7.46-7.42(\mathrm{~m}, 2 \mathrm{H})$, 7.32-7.26 (m, 2H), 7.18-7.14 (m, 2H), $7.09(\mathrm{~s}, 1 \mathrm{H}), 6.99-6.95(\mathrm{~m}, 2 \mathrm{H}), 6.89(\mathrm{~d}, 1 \mathrm{H}, \mathrm{J}=15.9 \mathrm{~Hz})$, 
3.84 (s, 3H), 3.62 (s, 3H), 2.35 (s, 3H). ${ }^{13} \mathrm{C} \mathrm{NMR}\left(100 \mathrm{MHz}, \mathrm{CDCl}_{3}\right): \delta 159.56,146.67,138.28$, 134.35, 134.14, 132.46, 130.29 (2C), 129.56 (2C), 127.63, 126.79 (2C), 122.56, 114.32 (2C), 113.05, 55.45, 31.15, 21.41. EI-MS m/z (\%): 304 (30), 303 (100), 288 (5), 259 (10), 144 (5). ESI-MS (+): $m / z(\%)=305(100)[\mathrm{M}+\mathrm{H}]^{+} . \mathrm{C}_{20} \mathrm{H}_{20} \mathrm{~N}_{2} \mathrm{O}$ (304.39): calcd. C, 78.92; H, 6.62; N, 9.20; found C, 79.02; H, 6.63; N, 9.22.

3.3.4. (E)-2-(2-(6-Methoxynaphthalen-2-yl)vinyl)-5-(4-methoxyphenyl)-1-methyl-1Himidazole $(\mathbf{3 e})$

The crude reaction product, which was obtained by Pd-catalyzed reaction of $\mathbf{1 a}$ with 2e (entry 5, Table 2), was purified by flash chromatography on silica gel with a mixture of toluene and AcOEt $(60 / 40)$ as eluent to give $3 \mathbf{e}(94.5 \mathrm{mg}, 51 \%$ yield) as brown solid: m.p. $=184-186{ }^{\circ} \mathrm{C} .{ }^{1} \mathrm{H}$ NMR $\left(200 \mathrm{MHz} \mathrm{CDCl}_{3}\right): \delta 7.83-7.70(\mathrm{~m}, 5 \mathrm{H}), 7.33-6.96(\mathrm{~m}, 8 \mathrm{H})$, 3.90-3.83 (m, 6H), $3.66(\mathrm{~s}, 3 \mathrm{H}) .{ }^{13} \mathrm{C} \mathrm{NMR}\left(50 \mathrm{MHz}, \mathrm{CDCl}_{3}\right): \delta 159.36,157.89,134.43,133.11$, $131.82,131.73,130.08$ (2C), 129.62, 128.85, 127.24, 127.10, 126.62, 123.80 (2C), 121.93, 119.03 (2C), 114.11, 113.83, 112.37, 105.80 (2C), 55.28 (2C), 31.17. EI-MS m/z (\%): 370 (52), 369 (100), 326(8), 281 (7), 207 (60). ESI-MS (+): $m / z(\%)=371(100)[\mathrm{M}+\mathrm{H}]^{+} \mathrm{C}_{24} \mathrm{H}_{22} \mathrm{~N}_{2} \mathrm{O}_{2}(370.45)$ : calcd. C, 77.81; H, 5.99; N, 7.56; found: C, 77.96; H, 6.00; N, 7.55.

\subsection{5. (E)-5-(4-Methoxyphenyl)-1-methyl-2-(4-nitrostyryl)-1H-imidazole (3f)}

The crude reaction product, which was obtained by Pd-catalyzed reaction of $1 \mathrm{a}$ with $\mathbf{2 g}$ (entry 6, Table 2), was purified by flash chromatography on silica gel with a mixture of toluene and AcOEt $(60 / 40)$ as eluent to give $3 \mathrm{f}(73.5 \mathrm{mg}, 44 \%$ yield $)$ as red solid: $\mathrm{m} . \mathrm{p}$. = 195-197 ${ }^{\circ} \mathrm{C} .{ }^{1} \mathrm{H}$ NMR $\left(200 \mathrm{MHz}, \mathrm{CDCl}_{3}\right): \delta 8.24-8.20(\mathrm{~m}, 2 \mathrm{H}),, 7.71-7.62(\mathrm{~m}, 3 \mathrm{H}), 7.35-7.26$ $(\mathrm{m}, 2 \mathrm{H}), 7.16(\mathrm{~s}, 1 \mathrm{H}), 7.08-6.95(\mathrm{~m}, 3 \mathrm{H}), 3.87(\mathrm{~s}, 3 \mathrm{H}), 3.71(\mathrm{~s}, 3 \mathrm{H}) .{ }^{13} \mathrm{C} \mathrm{NMR}\left(50 \mathrm{MHz}, \mathrm{CDCl}_{3}\right)$ : $\delta 159.66,146.88,145.33,143.26,135.39,130.23$ (2C), $129.16128 .43,127.04$ (2C), 124.20 (2C), 121.83, 117.86, 114.31 (2C), 55.46, 31.25. EI-MS m/z (\%): 335 (28), 334 (100), 304(14), 288 (38), 207 (13). ESI-MS (+): $m / z(\%)=336(100)[\mathrm{M}+\mathrm{H}]^{+} . \mathrm{C}_{19} \mathrm{H}_{17} \mathrm{~N}_{3} \mathrm{O}_{3}$ (335.36): calcd. C, 68.05; $\mathrm{H}$, $5.11 ; \mathrm{N}, 12.53$; found $\mathrm{C}, 68.18 ; \mathrm{H}, 5.12 ; \mathrm{N}, 12.52$.

\subsection{6. (E)-1-Methyl-2-styryl-5-(4-(trifluoromethyl)phenyl)-1H-imidazole (3g)}

The crude reaction product, which was obtained by Pd-catalyzed reaction of $\mathbf{1} \mathbf{b}$ with 2a (entry 7, Table 2), was purified by flash chromatography on silica gel with a mixture of toluene and AcOEt (80/20) as eluent to give $3 \mathrm{~g}(70.6 \mathrm{mg}, 43 \%$ yield) as yellow solid: m.p. $=163-165{ }^{\circ} \mathrm{C} .{ }^{1} \mathrm{H}$ NMR $\left(400 \mathrm{MHz} \mathrm{CDCl}_{3}\right): \delta 7.73-7.65(\mathrm{~m}, 3 \mathrm{H}), 7.58-7.47(\mathrm{~m}, 4 \mathrm{H})$, 7.40-7.35 (m, 2H), 7.32-7.28 (m, 1H), $7.22(\mathrm{~s}, 1 \mathrm{H}), 6.97(\mathrm{~d}, 1 \mathrm{H}, J=15.9 \mathrm{~Hz}), 3.71(\mathrm{~s}, 3 \mathrm{H}) .{ }^{13} \mathrm{C}$ NMR $\left(100 \mathrm{MHz}, \mathrm{CDCl}_{3}\right): \delta 147.91,133.74,133.70,133.68,133.26,129.85$ (q, 1C, J = $\left.32.6 \mathrm{~Hz}\right)$, 129.26, $128.92(2 \mathrm{C}), 128.72(2 \mathrm{C}), 128.59,126.99(2 \mathrm{C}), 125.91$ (q, 2C, J = 3,75 Hz), 124.14 (q, 1C, $J=272.2 \mathrm{~Hz}), 113.49,31.51$. EI-MS $m / z$ (\%): 328 (30), 327 (100), 312 (10), 128 (5). ESI-MS (+): $m / z(\%)=329(100)[\mathrm{M}+\mathrm{H}]^{+} . \mathrm{C}_{19} \mathrm{H}_{15} \mathrm{~F}_{3} \mathrm{~N}_{2}$ (328.34): calcd. C, 69.50; H, 4.61; N, 8.53; found C, $69.60 ; \mathrm{H}, 4.62 ; \mathrm{N}, 8.52$.

3.3.7. (E)-2-(4-Methoxystyryl)-1-methyl-5-(4-(trifluoro-methyl)phenyl)-1H-imidazole (3h)

The crude reaction product, which was obtained by Pd-catalyzed reaction of $\mathbf{1} \mathbf{b}$ with 2b (entry 8, Table 2), was purified by flash chromatography on silica gel with a mixture of toluene and AcOEt (60/40) as eluent to give $3 \mathrm{~h}(73.4 \mathrm{mg}, 41 \%$ yield) as yellow solid: m.p. $=193-195{ }^{\circ} \mathrm{C} .{ }^{1} \mathrm{H}$ NMR $\left(400 \mathrm{MHz}, \mathrm{CDCl}_{3}\right): \delta 7.71-7.67(\mathrm{~m}, 2 \mathrm{H}), 7.63(\mathrm{~d}, 1 \mathrm{H}, \mathrm{J}=15.8$ $\mathrm{Hz}), 7.54-7.46(\mathrm{~m}, 4 \mathrm{H}), 7.21(\mathrm{~s}, 1 \mathrm{H}), 6.93-6.89(\mathrm{~m}, 2 \mathrm{H}), 6.83(\mathrm{~d}, 1 \mathrm{H}, J=15.9 \mathrm{~Hz}), 3.83(\mathrm{~s}, 3 \mathrm{H})$, $3.69(\mathrm{~s}, 3 \mathrm{H}) .{ }^{13} \mathrm{C}$ NMR $\left(100 \mathrm{MHz}, \mathrm{CDCl}_{3}\right): \delta 160.13,148.34,133.81,133.43,133.00,129.75(\mathrm{q}$, $1 \mathrm{C}, J=32.9 \mathrm{~Hz}), 129.40,129.12,128.70(2 \mathrm{C}), 128.41(2 \mathrm{C}), 125.87(\mathrm{q}, 2 \mathrm{C}, J=3.7 \mathrm{~Hz}), 124.16(\mathrm{q}$, $1 C, J=271.8 \mathrm{~Hz}), 114.39$ (2C), 111.36, 55.45, 31.49. EI-MS $m / z(\%): 358$ (30), 357 (100), 342 (8), 314 (15), 299 (8). ESI-MS (+): $m / z(\%)=359$ (100) $[\mathrm{M}+\mathrm{H}]^{+} . \mathrm{C}_{20} \mathrm{H}_{17} \mathrm{~F}_{3} \mathrm{~N}_{2} \mathrm{O}$ (358.36): calcd. C, 67.03; H, 4.78; N, 7.82; found C, 67.16; H, 4.79; N, 7.81. 
3.3.8. (E)-1-Methyl-2-(4-methylstyryl)-5-(4-(trifluoro-methyl)phenyl)-1H-imidazole (3i)

The crude reaction product, which was obtained by Pd-catalyzed reaction of $\mathbf{1 b}$ with $\mathbf{2 d}$ (entry 9, Table 2), was purified by flash chromatography on silica gel with a mixture of toluene and AcOEt (40/60) as eluent to give $3 \mathbf{i}(75.3 \mathrm{mg}$, $44 \%$ yield) as yellow solid: m.p. $=200-202{ }^{\circ} \mathrm{C} .{ }^{1} \mathrm{H}$ NMR $\left(400 \mathrm{MHz}, \mathrm{CDCl}_{3}\right): \delta 7.71-7.67(\mathrm{~m}, 2 \mathrm{H}), 7.65(\mathrm{~d}, 1 \mathrm{H}$, $J=15.9 \mathrm{~Hz}), 7.52-7.48(\mathrm{~m}, 2 \mathrm{H}), 7.47-7.43(\mathrm{~m}, 2 \mathrm{H}), 7.21(\mathrm{~s}, 1 \mathrm{H}), 7.20-7.16(\mathrm{~m}, 2 \mathrm{H}), 6.91(\mathrm{~d}, 1 \mathrm{H}$, $J=15.8 \mathrm{~Hz}), 3.69(\mathrm{~s}, 3 \mathrm{H}), 2.36(\mathrm{~s}, 3 \mathrm{H}) .{ }^{13} \mathrm{C}$ NMR $\left(100 \mathrm{MHz}, \mathrm{CDCl}_{3}\right): \delta 148.13,138.70,133.83$, $133.75,133.12,129.75(\mathrm{q}, 1 \mathrm{C}, J=32.7 \mathrm{~Hz}), 129.64(2 \mathrm{C}), 129.19(2 \mathrm{C}), 128.67(2 \mathrm{C}), 126.94(2 \mathrm{C})$, $125.87(\mathrm{q}, 2 \mathrm{C}, J=3,70 \mathrm{~Hz}), 124.23(\mathrm{q}, 1 \mathrm{C}, J=272.0 \mathrm{~Hz}), 112.50,31.50,21.44$. EI-MS $\mathrm{m} / z(\%)$ : 342 (30), 341 (100), 326 (5), 170 (5). ESI-MS (+): $m / z(\%)=343(100)[\mathrm{M}+\mathrm{H}]^{+} . \mathrm{C}_{20} \mathrm{H}_{17} \mathrm{~F}_{3} \mathrm{~N}_{2}$ (342.37): calcd. C, 70.16; H, 5.01; N, 8.18; found C, 70.20; H, 5.02; N, 8.17.

3.3.9. (E)-1-methyl-5-(4-Trifluoromethyl)phenyl)-2-(4-(trifluoromethyl)-styryl)-1Himidazole (3j)

The crude reaction product, which was obtained by Pd-catalyzed reaction of $\mathbf{1 b}$ with 2c (entry 10, Table 2), was purified by flash chromatography on silica gel with a mixture of petroleum ether and AcOEt (70/30) as eluent to give $3 \mathbf{j}(82.7 \mathrm{mg}, 50 \%$ yield) as yellow solid: m.p. $=146-148{ }^{\circ} \mathrm{C} .{ }^{1} \mathrm{H}$ NMR $\left(400 \mathrm{MHz}, \mathrm{CDCl}_{3}\right): \delta 7.75-7.61(\mathrm{~m}, 7 \mathrm{H}), 7.55-7.51(\mathrm{~m}$, 2H), $7.25(\mathrm{~s}, 1 \mathrm{H}), 7.06(\mathrm{~d}, 1 \mathrm{H}, J=15.8 \mathrm{~Hz}), 3.75 .(\mathrm{s}, 3 \mathrm{H}) .{ }^{13} \mathrm{C} \mathrm{NMR}\left(100 \mathrm{MHz}, \mathrm{CDCl}_{3}\right): \delta$ $147.24,140.07,133.75,133.48,131.87,130.12(\mathrm{q}, 2 \mathrm{C}, \mathrm{J}=32.7 \mathrm{~Hz}), 129.57,128.86(2 \mathrm{C}), 127.07$ (2C), $125.99(\mathrm{q}, 2 \mathrm{C}, J=3.8 \mathrm{~Hz}), 125.89(\mathrm{q}, 2 \mathrm{C}, J=3.8 \mathrm{~Hz}), 124.24(\mathrm{q}, 1 \mathrm{C}, J=271.8 \mathrm{~Hz}), 124.14$ (q, 1C, J = 271.8 Hz), 115.77, 31.55. EI-MS m/z (\%): 396 (30), 395 (100), 380 (10), 378 (10), 327 (5), 196 (5). ESI-MS (+): $m / z(\%)=397(100)[\mathrm{M}+\mathrm{H}]^{+} . \mathrm{C}_{20} \mathrm{H}_{14} \mathrm{~F}_{6} \mathrm{~N}_{2}$ (396.34): calcd. C, 60.61; $\mathrm{H}, 3.56 ; \mathrm{N}, 7.07$; found $\mathrm{C}, 60.55 ; \mathrm{H}, 3.57 ; \mathrm{N}, 7.06$.

\subsubsection{0. (E)-5-(4-Chlorophenyl)-1-methyl-2-styryl-1H-imidazole (3k)}

The crude reaction product, which was obtained by Pd-catalyzed reaction of $1 \mathrm{c}$ with 2a (entry 11, Table 2), was purified by flash chromatography on silica gel with a mixture of $\mathrm{CH}_{2} \mathrm{Cl}_{2}$ and $\mathrm{MeOH}(97 / 3)$ as eluent to give $3 \mathbf{k}(70.5 \mathrm{mg}, 45 \%$ yield) as yellow solid: m.p. $=163-165{ }^{\circ} \mathrm{C} .{ }^{1} \mathrm{H}$ NMR $\left(400 \mathrm{MHz}, \mathrm{CDCl}_{3}\right)$ 8: $7.65(\mathrm{~d}, 1 \mathrm{H}, J=15.9 \mathrm{~Hz}), 7.56-7.52$ $(\mathrm{m}, 2 \mathrm{H}), 7.45-7.27(\mathrm{~m}, 7 \mathrm{H}), 7.15(\mathrm{~s}, 1 \mathrm{H}), 6.95(\mathrm{~d}, 1 \mathrm{H}, J=15.9 \mathrm{~Hz}), 3.65(\mathrm{~s}, 3 \mathrm{H}) .{ }^{13} \mathrm{C}$ NMR (100 MHz, $\mathrm{CDCl}_{3}$ ): $\delta 147.28,136.70,134.07,133.48,133.17,129.99$ (2C), 129.14 (2C), 128.88 (2C), 128.51, 128.44, 126.92 (2C), 113.67, 31.31. EI-MS m/z (\%): 296 (10), 295 (30), 294 (28), 293 (100), 278 (10), 128 (10). ESI-MS (+): $m / z(\%)=295$ (100), $297(39)[\mathrm{M}+\mathrm{H}]^{+} . \mathrm{C}_{18} \mathrm{H}_{15} \mathrm{ClN}_{2}$ (294.78): calcd. C, 73.34; H, 5.13; N, 9.50; found C, 73.15; H, 5.14; N, 9.49.

\subsubsection{1. (E)-5-(4-Chlorophenyl)-2-(4-methoxystyryl)-1-methyl-1H-imidazole (31)}

The crude reaction product, which was obtained by Pd-catalyzed reaction of $\mathbf{1 c}$ with $\mathbf{2 b}$ (entry 12 , Table 2 ), was purified by flash chromatography on silica gel with a mixture of toluene and AcOEt (70/30) to give 31 (45.4 mg, 28\% yield) as yellow solid: m.p. $=169-171{ }^{\circ} \mathrm{C} .{ }^{1} \mathrm{H}$ NMR $\left(400 \mathrm{MHz}, \mathrm{CDCl}_{3}\right): \delta 7.59(\mathrm{~d}, 1 \mathrm{H}, J=15.8 \mathrm{~Hz}), 7.50-7.46$ $(\mathrm{m}, 2 \mathrm{H}), 7.42-7.38(\mathrm{~m}, 2 \mathrm{H}), 7.31-7.27(\mathrm{~m}, 2 \mathrm{H}), 7.12(\mathrm{~s}, 1 \mathrm{H}), 6.91-687(\mathrm{~m}, 2 \mathrm{H}), 6.80(\mathrm{~d}, 1 \mathrm{H}$, $J=15.9 \mathrm{~Hz}), 3.81(\mathrm{~s}, 3 \mathrm{H}), 3.62(\mathrm{~s}, 3 \mathrm{H}) .{ }^{13} \mathrm{C} \mathrm{NMR}\left(100 \mathrm{MHz}, \mathrm{CDCl}_{3}\right): \delta 159.96,147.62,133.88$, $133.17,132.83,129.88$ (2C), 129.44, 129.06 (2C), 128.62, 128.25, 128.23, 114.30 (2C), 111.51, 55.39, 31.25. EI-MS $m / z$ (\%): 326 (10), 325 (34), 324 (32), 323 (100), 308 (7), 280 (10). ESI-MS $(+): m / z(\%)=325(100), 327(36)[\mathrm{M}+\mathrm{H}]^{+} . \mathrm{C}_{19} \mathrm{H}_{17} \mathrm{ClN}_{2} \mathrm{O}$ (324.81): calcd. C, 70.26; $\mathrm{H}, 5.28 ;$ $\mathrm{N}, 8.62$; found $\mathrm{C}, 70.41 ; \mathrm{H}, 5.27 ; \mathrm{N}, 8.63$.

\subsubsection{2. (E)-5-(4-Chlorophenyl)-1-methyl-2-(4-(trifluoromethyl)styryl)-1H-imidazole (3m)}

The crude reaction product, which was obtained by Pd-catalyzed reaction of $1 \mathbf{c}$ with 2c (entry 13, Table 2), was purified by flash chromatography on silica gel with a mixture of $\mathrm{CH}_{2} \mathrm{Cl}_{2}$ and $\mathrm{MeOH}(99 / 1)$ to give $3 \mathrm{~m}(83.3 \mathrm{mg}, 46 \%$ yield) as an orange solid: m.p. $=127-129{ }^{\circ} \mathrm{C} .{ }^{1} \mathrm{H}$ NMR $\left(400 \mathrm{MHz}, \mathrm{CDCl}_{3}\right): \delta 7.70-7.58(\mathrm{~m}, 5 \mathrm{H}), 7.47-7.43(\mathrm{~m}, 2 \mathrm{H})$, 7.35-7.31 (m, 2H), $7.18(\mathrm{~s}, 1 \mathrm{H}), 7.05(\mathrm{~d}, 1 \mathrm{H}, J=15.9 \mathrm{~Hz}), 3.70(\mathrm{~s}, 3 \mathrm{H}) .{ }^{13} \mathrm{C}$ NMR $(100 \mathrm{MHz}$, 
$\left.\mathrm{CDCl}_{3}\right): \delta 146.68,140.22,134.41,134.04,131.37,130.13(2 \mathrm{C}), 130.05(\mathrm{q}, 1 \mathrm{C}, J=32.7 \mathrm{~Hz})$, $129.27(2 \mathrm{C}), 128.93,128.39,127.03(2 \mathrm{C}), 125.90(\mathrm{q}, 2 \mathrm{C}, J=3.8 \mathrm{~Hz}), 124,92(\mathrm{q}, 1 \mathrm{C}, J=271.9 \mathrm{~Hz})$, 115.98, 31.40. EI-MS m/z (\%): 364 (10), 363 (35), 362 (30), 361 (100), 346 (10), 196 (5). ESI-MS $(+): m / z(\%)=363(100), 365(38)[\mathrm{M}+\mathrm{H}]^{+} . \mathrm{C}_{19} \mathrm{H}_{14} \mathrm{ClF}_{3} \mathrm{~N}_{2}$ (362.78): calcd. C, 62.91; H, 3.89; $\mathrm{N}, 7.72$; found $\mathrm{C}, 62.89 ; \mathrm{H}, 3.90 ; \mathrm{N}, 7.71$.

\subsubsection{3. (E)-4-(2-(5-(4-Chlorophenyl)-1-methyl-1H-imidazol-2-yl)vinyl)-pyridine (3n)}

The crude reaction product, which was obtained by Pd-catalyzed reaction of $1 \mathrm{c}$ with $\mathbf{2 f}$ (entry 14, Table 2), was purified by flash chromatography on silica gel with a mixture of $\mathrm{CH}_{2} \mathrm{Cl}_{2}$ and $\mathrm{MeOH}(97 / 3)$ to give $3 \mathrm{n}\left(23.8 \mathrm{mg}, 16 \%\right.$ yield) as pale brown wax. ${ }^{1} \mathrm{H}$ NMR $\left(200 \mathrm{MHz}, \mathrm{CDCl}_{3}\right): \delta 7.60-6.98(\mathrm{~m}, 9 \mathrm{H}), 3.71(\mathrm{~s}, 3 \mathrm{H}) .{ }^{13} \mathrm{C} \mathrm{NMR}\left(50 \mathrm{MHz}, \mathrm{CDCl}_{3}\right): \delta 149.99$, $143.7,134.22$ (2C), 131.32, 129.86 (2C), 129.75 (2C), 129.18, 129.01 (2C), 128.80 (2C), 127.87, 117.58, 31.29. EI-MS m/z (\%): 297 (9), 296 (36), 295 (27), 294 (100), 279 (6), 242 (4). ESI-MS $(+): m / z(\%)=296(100), 298(35)[\mathrm{M}+\mathrm{H}]^{+} . \mathrm{C}_{17} \mathrm{H}_{14} \mathrm{ClN}_{3}$ (295.77): calcd. C, 69.04; H, 4.77; N, 14.21; found $\mathrm{C}, 69.01 ; \mathrm{H}, 4.78 ; \mathrm{N}, 14.20$.

\subsubsection{4. (E)-5-(4-Chlorophenyl)-1-methyl-2-(4-nitrostyryl)-1H-imidazole (3o)}

The crude reaction product, which was obtained by Pd-catalyzed reaction of $1 c$ with $\mathbf{2 g}$ (entry 15, Table 2), was purified by flash chromatography on silica gel with a mixture of toluene and AcOEt (70/30) to give $30(45.8 \mathrm{mg}, 27 \%$ yield) as pale red solid: m.p. $=187-189{ }^{\circ} \mathrm{C} .{ }^{1} \mathrm{H}$ NMR $\left(200 \mathrm{MHz}, \mathrm{CDCl}_{3}\right): \delta 8.24-8.20(\mathrm{~m}, 2 \mathrm{H}), 7.74-7.60(\mathrm{~m}, 3 \mathrm{H})$, 7.49-7.06 (m, 6H), $3.73(\mathrm{~s}, 3 \mathrm{H}) .{ }^{13} \mathrm{C}$ NMR $\left(100 \mathrm{MHz}, \mathrm{CDCl}_{3}\right): \delta 147.01,146.07,142.99,134.34$ (2C), 131.64, 129.95 (2C), 129.12 (2C), 128.18, 127.94, 127.13 (2C), 124.19 (2C), 117.50, 31.36. EI-MS m/z (\%): 341 (10), 340 (37), 339 (35), 338 (100), 308 (15), 292 (40). ESI-MS (+): $m / z$ $(\%)=340$ (100), $342(37)[\mathrm{M}+\mathrm{H}]^{+} . \mathrm{C}_{18} \mathrm{H}_{14} \mathrm{ClN}_{3} \mathrm{O}_{2}$ (339.78): calcd. C, 63.63; H, 4.15; N, 12.37; found $\mathrm{C}, 63.65 ; \mathrm{H}, 4.14 ; \mathrm{N}, 12.38$.

\subsubsection{5. (E)-5-(3-Fluoro-4-methoxyphenyl)-2-(4-methoxystyryl)-1-methyl-1H-imidazole (3p)}

The crude reaction product, which was obtained by Pd-catalyzed reaction of $\mathbf{1 d}$ with $\mathbf{2 b}$ (entry 16, Table 2), was purified by flash chromatography on silica gel with a mixture of $\mathrm{CH}_{2} \mathrm{Cl}_{2}$ and $\mathrm{MeOH}(97 / 3)$ to give $3 \mathrm{p}\left(94.7 \mathrm{mg}, 56 \%\right.$ yield) as beige solid: m.p. $=70{ }^{\circ} \mathrm{C}$. ${ }^{1} \mathrm{H}$ NMR $\left(200 \mathrm{MHz} \mathrm{CDCl}_{3}\right): \delta 7.67(\mathrm{~d}, 1 \mathrm{H}, J=15.6 \mathrm{~Hz}), 7.53-7.49(\mathrm{~m}, 2 \mathrm{H}), 7.27(\mathrm{~s}, 1 \mathrm{H})$, 7.14-6.76 (m, 7H), 3.94(s, 3H), 3.84(s, 3H), 3.65 (s, 3H). $\left.{ }^{13} \mathrm{C} \mathrm{NMR} \mathrm{(50} \mathrm{MHz,} \mathrm{CDCl}\right): \delta 160.11$, $150.73(\mathrm{~d}, 1 \mathrm{C}, J=393.0 \mathrm{~Hz}), 147.90(\mathrm{~d}, 1 \mathrm{C}, J=10.6 \mathrm{~Hz}), 133.82,133.11,129.29,128.43(2 \mathrm{C})$, 126.82, $125.09(\mathrm{~d}, 1 \mathrm{C}, J=3.3 \mathrm{~Hz}), 122.63(\mathrm{~d}, 1 \mathrm{C}, J=7.2 \mathrm{~Hz}), 116.69(\mathrm{~d}, 1 \mathrm{C}, J=19.03 \mathrm{~Hz})$, $114.48(2 \mathrm{C}), 113.77(\mathrm{~d}, 1 \mathrm{C}, J=2.42 \mathrm{~Hz}), 110.77,56.51,55.52,31.44$. EI-MS $m / z(\%): 338$ (38), 337 (100), 322 (10), 169 (5). ESI-MS (+): $m / z(\%)=339(100)[\mathrm{M}+\mathrm{H}]^{+} . \mathrm{C}_{20} \mathrm{H}_{19} \mathrm{FN}_{2} \mathrm{O}_{2}(338.38)$ : calcd. C, 70.99; H, 5.66; N, 8.28; found C, 70.89; H, 5.67; N, 8.29.

\subsubsection{6. (E)-2-(4-Methoxystyryl)-1-methyl-5-(4-nitrophenyl)-1H-imidazole (3q)}

The crude reaction product, which was obtained by Pd-catalyzed reaction of $1 \mathbf{e}$ with 2b (entry 17, Table 2), was purified by flash chromatography on silica gel with a mixture of $\mathrm{CH}_{2} \mathrm{Cl}_{2}$ and $\mathrm{MeOH}(97 / 3)$ to give $3 q$ (54.5 mg, 30\% yield) as red solid: m.p. $=190-192{ }^{\circ} \mathrm{C}$. ${ }^{1} \mathrm{H}$ NMR $\left(200 \mathrm{MHz}, \mathrm{CDCl}_{3}\right): \delta 8.33-8.29(\mathrm{~m}, 2 \mathrm{H}), 7.65(\mathrm{~d}, 1 \mathrm{H}, J=15.8 \mathrm{~Hz}), 7.60-7.45(\mathrm{~m}, 4 \mathrm{H})$, 7.30-7.26 (m, 2H), 6.94-6.90 (m, 2H), $6.83(\mathrm{~d}, 1 \mathrm{H}, J=15.8 \mathrm{~Hz}), 3.84(\mathrm{~s}, 3 \mathrm{H}), 3.75(\mathrm{~s}, 3 \mathrm{H}) .{ }^{13} \mathrm{C}$ $\mathrm{NMR}\left(50 \mathrm{MHz}, \mathrm{CDCl}_{3}\right) \delta 160.20,149.27,146.74,136.53,134.23,132.26,130.28,129.11,128.43$ (2C), 128.34 (2C), 124.34 (2C), 114.37 (2C), 110.91, 55.51, 31.86. EI-MS m/z (\%): 335 (33), 334 (100), 304 (22), 288 (32). ESI-MS (+): $m / z(\%)=336(100)[\mathrm{M}+\mathrm{H}]^{+} \mathrm{C}_{19} \mathrm{H}_{17} \mathrm{~N}_{3} \mathrm{O}_{3}(335.36)$ : calcd. C, 68.05; H, 5.11; N, 12.53; found C, 68.11; H, 5.12; N, 12.55 .

\subsubsection{7. (E)-5-(Benzo[d][1,3]dioxol-5-yl)-2-(4-methoxystyryl)-1-methyl-1H-imidazole (3r)}

The crude reaction product, which was obtained by Pd-catalyzed reaction of $\mathbf{1 f}$ with $\mathbf{2 b}$ (entry 18, Table 2), was purified by flash chromatography on silica gel with a mixture of $\mathrm{CH}_{2} \mathrm{Cl}_{2}$ and $\mathrm{MeOH}(98 / 2)$ to give 3 r (54.5 mg, 52\% yield) as pale red wax. ${ }^{1} \mathrm{H}$ NMR 
$\left(200 \mathrm{MHz} \mathrm{CDCl}_{3}\right): \delta 7.58(\mathrm{~d}, 1 \mathrm{H}, J=15.8 \mathrm{~Hz}), 7.51-7.47(\mathrm{~m}, 2 \mathrm{H}), 7.07(\mathrm{~s}, 1 \mathrm{H}), 6.93-6.76(\mathrm{~m}$, $8 \mathrm{H}), 6.01(\mathrm{~s}, 2 \mathrm{H}), 3.83(\mathrm{~s}, 3 \mathrm{H}), 3.63(\mathrm{~s}, 3 \mathrm{H}) .{ }^{13} \mathrm{C} \mathrm{NMR}\left(50 \mathrm{MHz}, \mathrm{CDCl}_{3}\right) \delta$ 160.04, 148.09, 147.75, $146.84,134.18,133.10,129.55,128.37$ (2C), 127.11, 123.69, 122.93, 114.40 (2C), 111.38,109.47, 108.82, 101.55, 55.56, 31.42. EI-MS m/z (\%): 334 (38), 333 (100), 318 (4), 290 (6). ESI-MS (+): $m / z(\%)=335(100)[\mathrm{M}+\mathrm{H}]^{+} . \mathrm{C}_{20} \mathrm{H}_{18} \mathrm{~N}_{2} \mathrm{O}_{3}$ (334.38): calcd. C, 71.84; $\mathrm{H}, 5.43 ; \mathrm{N}, 8.38$; found C, 71.88; H, 5.44; N, 8.37.

\subsubsection{8. (E)-1-Methyl-2-styryl-1H-benzo[d]imidazole (8)}

The crude reaction product, which was obtained by Pd-catalyzed reaction of 6 with $2 \mathbf{a}$ (Scheme 5), was purified by flash chromatography on silica gel with a mixture of $\mathrm{CH}_{2} \mathrm{Cl}_{2}$ and AcOEt (99/1) to give 8 (101.8 mg, 87\% yield) as beige solid: m.p. $118-120^{\circ} \mathrm{C}$, lit [51] mp 119-121 ${ }^{\circ} \mathrm{C} .{ }^{1} \mathrm{H}$ NMR $\left(200 \mathrm{MHz} \mathrm{CDCl}_{3}\right): \delta 7.97(\mathrm{~d}, 1 \mathrm{H}, J=15.9 \mathrm{~Hz}), 7.83-7.72(\mathrm{~m}$, 1H), 7.65-7.58 (m, 2H) 7.47-7.19 (m, 6H), $7.09(\mathrm{~d}, 1 \mathrm{H}, J=15.9 \mathrm{~Hz}), 3.83(\mathrm{~s}, 3 \mathrm{H}) .{ }^{13} \mathrm{C} \mathrm{NMR}$ $\left(50 \mathrm{MHz}, \mathrm{CDCl}_{3}\right) \delta 150.91,143.02,137.02,135.91,128.97,128.78$ (2C), 127.17 (2C), 122.52 (2C), 119.12, 112.90 (2C), 109.17, 29.52. EI-MS m/z (\%): 234 (36), 233 (100), 219 (7), 218 (19), 117 (7). ESI-MS (+): $m / z(\%)=235(100)[\mathrm{M}+\mathrm{H}]^{+} . \mathrm{C}_{16} \mathrm{H}_{14} \mathrm{~N}_{2}$ (234.30): calcd. C, 82.02; H, 6.02; N, 11.96; found C, 82.11; H, 6.03; N, 12.00 .

\subsubsection{9. (E)-2-Styryl-1H-benzo[d]imidazole (9)}

The crude reaction product, which was obtained by Pd-catalyzed reaction of 7 with $\mathbf{2 a}$ (Scheme 5), was purified by flash chromatography on silica gel with a mixture of toluene and AcOEt (50/50) to give 9 (70.0 mg, 64\% yield) as white solid: m.p. 195-197 ${ }^{\circ} \mathrm{C}$; lit.[52] mp $195^{\circ} \mathrm{C} .{ }^{1} \mathrm{H}$ NMR $\left(400 \mathrm{MHz}, \mathrm{CDCl}_{3}+\mathrm{DMSO}-d 6\right): \delta 7.71(\mathrm{~d}, 1 \mathrm{H}, J=16.5 \mathrm{~Hz}), 7.60(\mathrm{br}, 2 \mathrm{H})$, 7.51-7.47 (m, 2H), 7.36-7.25 (m, 4H), 7.24-7.15 (m, 3H). ${ }^{13} \mathrm{C} \mathrm{NMR} \mathrm{(100} \mathrm{MHz,} \mathrm{CDCl} 3+$ DMSOd6): $\delta 151.37,135.89,134.96,128.71$ (3C), 128.67 (2C), 126.88 (3C), 122.39 (3C), 117.21. EI-MS $m / z(\%): 220$ (32), 219 (100), $218(14), 109$ (7). ESI-MS (+): $m / z(\%)=221(100)[\mathrm{M}+\mathrm{H}]^{+}$. $\mathrm{C}_{15} \mathrm{H}_{12} \mathrm{~N}_{2}$ (220.28): calcd. C, 81.79; H, 5.49; N, 12.72; found C, 81.84; $\mathrm{H}, 5.50 ; \mathrm{N}, 12.75$. The NMR spectroscopic data of this compound were in agreement with those previously reported [52].

\subsubsection{0. (E)-2-Styrylbenzo[d]oxazole (11)}

The crude reaction product, which was obtained by Pd-catalyzed reaction of $\mathbf{1 0}$ with 2a (Scheme 5), was purified by flash chromatography on silica gel with a mixture of toluene and AcOEt (95/5) to give 11 (33.2 mg, 30\% yield) as brown solid: m.p. 84-86 ${ }^{\circ} \mathrm{C}$, lit.[53] mp 86-88 ${ }^{\circ} \mathrm{C} .{ }^{1} \mathrm{H}$ NMR $\left(200 \mathrm{MHz}, \mathrm{CDCl}_{3}\right): \delta 7.78(\mathrm{~d}, 1 \mathrm{H}, J=16.4 \mathrm{~Hz}), 7.73-7.65(\mathrm{~m}, 1 \mathrm{H})$, 7.62-7.48 (m, 3H), 7.45-7.28 (m, 6H), $7.07(\mathrm{~d}, 1 \mathrm{H}, J=16.4 \mathrm{~Hz}) .{ }^{13} \mathrm{C} \mathrm{NMR}\left(50 \mathrm{MHz}, \mathrm{CDCl}_{3}\right) \delta$ $162.79,150.42,142.23,139.54,135.20,129.86,129.81,129.05,128.19,127.64,125.30,124.59$, 119.95, 114.02, 110.42. EI-MS $m / z$ (\%): 221 (33), 220 (100), 191 (7), 165 (3). ESI-MS (+): $m / z$ $(\%)=222(100)[\mathrm{M}+\mathrm{H}]^{+} . \mathrm{C}_{15} \mathrm{H}_{11} \mathrm{NO}$ (221.26): calcd. C, 81.43; H, 5.01; N, 6.33; found C, 81.35; H, 5.02; N, 6.35. The NMR spectroscopic data of this compound were in agreement with those previously reported [53].

\subsubsection{1. (E)-1-Methyl-4,5-diphenyl-2-styryl-1H-imidazole (13)}

The crude reaction product, which was obtained by Pd-catalyzed reaction of $\mathbf{1 2}$ with 2a (Scheme 5), was purified by flash chromatography on silica gel with a mixture of toluene and AcOEt (93/7) to give $\mathbf{1 3}\left(89.0 \mathrm{mg}, 55 \%\right.$ yield) as orange glassy solid: m.p. $65-69{ }^{\circ} \mathrm{C}$. ${ }^{1} \mathrm{H} \mathrm{NMR}\left(400 \mathrm{MHz}, \mathrm{CDCl}_{3}\right): \delta 7.76(\mathrm{~d}, 1 \mathrm{H}, J=15.9 \mathrm{~Hz}), 7.60-7.56(\mathrm{~m}, 2 \mathrm{H}), 7.54-7.50(\mathrm{~m}$, $2 \mathrm{H}), 7.48-7.41(\mathrm{~m}, 3 \mathrm{H}), 7.40-7.26(\mathrm{~m}, 5 \mathrm{H}), 7.24-7.16(\mathrm{~m}, 2 \mathrm{H}), 7.00(\mathrm{~d}, 1 \mathrm{H}, J=15.9 \mathrm{~Hz})$, $3.53(\mathrm{~s}, 3 \mathrm{H}) .{ }^{13} \mathrm{C}$ NMR $\left(100 \mathrm{MHz}, \mathrm{CDCl}_{3}\right): \delta 145.50,138.56,136.96,134.75,133.00,131.02$ (2C), 130.22, 129.10 (2C), 128.87 (2C), 128.68, 128.29, 128.22(2C), $127.22(2 \mathrm{C}), 126.94(2 \mathrm{C})$, 126.54, 113.86, 31.13. EI-MS $m / z$ (\%): 336 (50), 335 (100), 319 (10), 165 (5). ESI-MS (+): $m / z(\%)=337(100)[\mathrm{M}+\mathrm{H}]^{+} . \mathrm{C}_{24} \mathrm{H}_{20} \mathrm{~N}_{2}$ (336.44): calcd. C, 85.68; H, 5.99; N, 8.33; found C, $85.76 ; \mathrm{H}, 6.01 ; \mathrm{N}, 8.35$. The NMR spectroscopic data of this compound were in agreement with those previously reported [54]. 


\subsubsection{2. (E)-4,5-Diphenyl-2-styryl-1H-imidazole (15)}

The crude reaction product, which was obtained by Pd-catalyzed reaction of $\mathbf{1 4}$ with 2a (Scheme 5), was purified by flash chromatography on silica gel with a mixture of $\mathrm{CH}_{2} \mathrm{Cl}_{2}$ and $\mathrm{MeOH}(95 / 5)$ to give 15 (59.6 mg, 36\% yield) as orange solid: m.p. $120-122{ }^{\circ} \mathrm{C} .{ }^{1} \mathrm{H}$ NMR (400 MHz, CDCl $): \delta 7.47-7.40(\mathrm{~m}, 4 \mathrm{H}), 7.38-7.32(\mathrm{~m}, 2 \mathrm{H}), 7.30-7.20(\mathrm{~m}, 10 \mathrm{H}), 7.00(\mathrm{~d}$, $1 \mathrm{H}, J=16.6 \mathrm{~Hz}) .{ }^{13} \mathrm{C}$ NMR $\left(100 \mathrm{MHz}, \mathrm{CDCl}_{3}\right): \delta 145.10,135.93,133.64,132.02,131.34,128.92$, 128.89 (2C), 128.81, 128.76 (5C), 128.07 (6C), 127.06 (2C), 114.44. EI-MS $m / z$ (\%): 322 (50), 321 (100), 165 (10), 115 (5). ESI-MS (+): $m / z(\%)=323(100)[\mathrm{M}+\mathrm{H}]^{+} . \mathrm{C}_{23} \mathrm{H}_{18} \mathrm{~N}_{2}(322.41)$ calcd. C, 85.68; H, 5.63; N, 8.69; found C, 85.78; H, 5.62; N, 8.70. The NMR spectroscopic data of this compound were in agreement with those previously reported [55].

\subsubsection{3. (E)-5-(4-Methoxyphenyl)-1,2-dimethyl-4-styryl-1H-imidazole (17)}

The crude reaction product, which was obtained by Pd-catalyzed reaction of $\mathbf{1 6}$ with 2a (Scheme 6), was purified by flash chromatography on silica gel with a mixture of $\mathrm{CH}_{2} \mathrm{Cl}_{2}$ and $\mathrm{MeOH}(96 / 4)$ to give $17\left(76.0 \mathrm{mg}, 50 \%\right.$ yield) as orange solid: m.p. $39-40{ }^{\circ} \mathrm{C} .{ }^{1} \mathrm{HNMR}$ $\left(400 \mathrm{MHz}, \mathrm{C}_{6} \mathrm{D}_{6}\right): \delta 8.00(\mathrm{~d}, J=15.8 \mathrm{~Hz}, 1 \mathrm{H}), 7.38-7.39(\mathrm{~m}, 2 \mathrm{H}), 7.25(\mathrm{~d}, J=15.8 \mathrm{~Hz}, 1 \mathrm{H})$, 7.05-7.10 (m, 4H), 6.95-6.99 (m, 1H), 6.81-6.84 (m, 2H), $3.35(\mathrm{~s}, 3 \mathrm{H}), 2.62(\mathrm{~s}, 3 \mathrm{H}), 2.08(\mathrm{~s}, 3 \mathrm{H})$. ${ }^{13} \mathrm{CNMR}\left(400 \mathrm{MHz}, \mathrm{C}_{6} \mathrm{D}_{6}\right): \delta 159.93,144.93,139.15,136.43,131.91(2 \mathrm{C}), 131.02,128.77(2 \mathrm{C})$, $126.99,126.64,126.55(2 \mathrm{C}) ; 123.16,120.90,114.53$ (2C), 54.90, 30.33, 13.49. EI-MS $(\mathrm{m} / \mathrm{z}): 304$ (100), 303 (95), 288 (5), 249 (15), 152 (6), 56 (11). ESI-MS (+): $m / z(\%)=305(100)[\mathrm{M}+\mathrm{H}]^{+}$. $\mathrm{C}_{20} \mathrm{H}_{20} \mathrm{~N}_{2} \mathrm{O}$ (304.39): calcd. C, 78.92; H, 6.62; N, 9.20; found C, 79.01; H, 6.63; N, 9.22.

\subsubsection{4. (E)-1-Methyl-2-styryl-1H-imidazole (19)}

The crude reaction product, which was obtained by Pd-catalyzed reaction of 18 with 2a (Scheme 7), was purified by flash chromatography on silica gel with a mixture of $\mathrm{CH}_{2} \mathrm{Cl}_{2}$ and $\mathrm{MeOH}(93: 7)$ as eluent to give $\mathrm{Y}(83 \mathrm{mg}, 45 \%)$ as a light brown oil. ${ }^{1} \mathrm{H}$ NMR $(400 \mathrm{MHz}$, $\left.\mathrm{CDCl}_{3}\right) \delta 7.59(\mathrm{~d}, 1 \mathrm{H}, J=16.08 \mathrm{~Hz}), 7.42-7.26(\mathrm{~m}, 5 \mathrm{H}), 7.11(\mathrm{~s}, 1 \mathrm{H}), 6.90(\mathrm{~s}, 1 \mathrm{H}), 6.85(\mathrm{~d}, 1 \mathrm{H}$, $J=16.06), 3.68(\mathrm{~s}, 3 \mathrm{H})$. EI-MS $m / z(\%)=184(25), 183$ (100), $168(12), 128$ (5), 115 (7). ESI-MS $(+): m / z(\%)=185(100)[\mathrm{M}+\mathrm{H}]^{+}$. The NMR spectroscopic data of this compound were in agreement with those previously reported [37].

\section{Conclusions}

In this work, we developed a simple and efficient $\mathrm{Pd}(\mathrm{II}) / \mathrm{Cu}(\mathrm{II})$-promoted dehydrogenative alkenylation of 5-arylimidazoles, 4,5-diphenylimidazole, benzimidazoles and benzoxazole with functionalized styrenes. Starting from a preliminary screening of the role of oxidant, catalyst precursors, solvents, and reaction temperature on the efficiency and selectivity of the alkenylation of 5-(4-methoxyphenyl)-1,2-dimethyl-1H-imidazole (1a) with styrene (2a) we were able to identify reaction conditions suitable for the simple preparation of several 2-alkenyl-substituted azoles. We believe that our findings may represent an important clue for late-stage functionalization protocols [56-58] involving imidazoles, because no pre-activation of the reactive bonds is required. Further studies on the application of this interesting methodology to the synthesis of new heteroaromatic organic fluorophores are underway.

Supplementary Materials: The following are available online at https:/ /www.mdpi.com/article/10 $.3390 /$ catal11070762/s1: ${ }^{1} \mathrm{H}$ and ${ }^{13} \mathrm{C}$ NMR spectra of all the new compounds.

Author Contributions: Conceptualization, F.B.; methodology, F.B., M.L. and A.C.; investigation, A.N., L.L. and M.P.; data curation, M.L., A.C.; writing—original draft preparation, F.B.; writing—review and editing, F.B., M.L. and A.C.; supervision, F.B. and M.L.; funding acquisition, F.B. All authors have read and agreed to the published version of the manuscript.

Funding: This research was funded by Università di Pisa under PRA 2020-2021 (project No. PRA_2020_21). 
Conflicts of Interest: The authors declare no conflict of interest.

\section{References}

1. Bansal, S.; Shabade, A.B.; Punji, B. Advances in $\mathrm{C}\left(\mathrm{sp}^{2}\right)-\mathrm{H} / \mathrm{C}\left(\mathrm{sp}^{2}\right)$-H Oxidative Coupling of (Hetero)arenes Using $3 \mathrm{~d}$ Transition Metal Catalysts. Adv. Synth. Catal. 2021, 363, 1998-2022. [CrossRef]

2. Bellina, F.; Perego, L.A. 12 Aerobic Oxidative Intermolecular Cross-Coupling and Heck Reactions; Georg Thieme Verlag: Stuttgart, Germany, 2017.

3. Jia, C.; Kitamura, T.; Fujiwara, Y. Catalytic functionalization of arenes and alkanes via C-H bond activation. Acc. Chem. Res. 2001, 34, 633-639. [CrossRef] [PubMed]

4. Le Bras, J.; Muzart, J. Intermolecular dehydrogenative Heck reactions. Chem. Rev. 2011, 111, 1170-1214. [CrossRef]

5. Liu, C.; Yuan, J.; Gao, M.; Tang, S.; Li, W.; Shi, R.; Lei, A. Oxidative Coupling between Two Hydrocarbons: An Update of Recent C-H Functionalizations. Chem. Rev. 2015, 115, 12138-12204. [CrossRef]

6. Maes, J.; Maes, B.U.W. A Journey through Metal-Catalyzed CH Functionalization of Heterocycles. In Heterocyclic Chemistry in the 21st Century - A Tribute to Alan Katritzky; Academic Press: Cambridge, MA, USA, 2016; pp. 137-194.

7. Varun, B.V.; Dhineshkumar, J.; Bettadapur, K.R.; Siddaraju, Y.; Alagiri, K.; Prabhu, K.R. Recent advancements in dehydrogenative cross coupling reactions for CC bond formation. Tetrahedron Lett. 2017, 58, 803-824. [CrossRef]

8. Wang, D.; Weinstein, A.B.; White, P.B.; Stahl, S.S. Ligand-Promoted Palladium-Catalyzed Aerobic Oxidation Reactions. Chem. Rev. 2018, 118, 2636-2679. [CrossRef]

9. Yang, Y.; Lan, J.; You, J. Oxidative C-H/C-H Coupling Reactions between Two (Hetero)arenes. Chem. Rev. 2017, 117, 8787-8863. [CrossRef] [PubMed]

10. Yeung, C.S.; Dong, V.M. Catalytic dehydrogenative cross-coupling: Forming carbon-carbon bonds by oxidizing two carbonhydrogen bonds. Chem. Rev. 2011, 111, 1215-1292. [CrossRef] [PubMed]

11. Bras, J.L.; Muzart, J. Pd-Catalyzed Intermolecular Dehydrogenative Heck Reactions of Five-Membered Heteroarenes. Catalysts 2020, 10, 571. [CrossRef]

12. Moritanl, I.; Fujiwara, Y. Aromatic substitution of styrene-palladium chloride complex. Tetrahedron Lett. 1967, 8, 1119-1122. [CrossRef]

13. Fujiwara, Y.; Moritani, I.; Danno, S.; Asano, R.; Teranishi, S. Aromatic substitution of olefins. VI. Arylation of olefins with palladium(II) acetate. J. Am. Chem. Soc. 1969, 91, 7166-7169. [CrossRef]

14. Moritani, I.; Danno, S.; Fujiwara, Y.; Teranishi, S. Aromatic Substitution of Olefins XV. The Steric Course of the Reaction. Bull. Chem. Soc. Jpn. 1971, 44, 578-579. [CrossRef]

15. Wu, Y.; Wang, J.; Mao, F.; Kwong, F.Y. Palladium-catalyzed cross-dehydrogenative functionalization of C( $\left.\mathrm{sp}^{2}\right)-\mathrm{H}$ Bonds. Chem. Asian J. 2014, 9, 26-47. [CrossRef] [PubMed]

16. Broggini, G.; Beccalli, E.M.; Fasana, A.; Gazzola, S. Palladium-catalyzed dual C-H or N-H functionalization of unfunctionalized indole derivatives with alkenes and arenes. Beilstein J. Org. Chem. 2012, 8, 1730-1746. [CrossRef] [PubMed]

17. Zhu, W.; Gunnoe, T.B. Advances in Group 10 Transition-Metal-Catalyzed Arene Alkylation and Alkenylation. J. Am. Chem. Soc. 2021, 143, 6746-6766. [CrossRef]

18. Heck, R.F.; Nolley, J.P. Palladium-catalyzed vinylic hydrogen substitution reactions with aryl, benzyl, and styryl halides. J. Org. Chem. 2002, 37, 2320-2322. [CrossRef]

19. Mizoroki, T.; Mori, K.; Ozaki, A. Arylation of Olefin with Aryl Iodide Catalyzed by Palladium. Bull. Chem. Soc. Jpn. 1971, 44, 581. [CrossRef]

20. Besselievre, F.; Piguel, S.; Mahuteau-Betzer, F.; Grierson, D.S. Stereoselective direct copper-catalyzed alkenylation of oxazoles with bromoalkenes. Org. Lett. 2008, 10, 4029-4032. [CrossRef]

21. Gottumukkala, A.L.; Derridj, F.; Djebbar, S.; Doucet, H. Alkenyl bromides: Useful coupling partners for the palladium-catalysed coupling with heteroaromatics via a C-H bond activation. Tetrahedron Lett. 2008, 49, 2926-2930. [CrossRef]

22. Verrier, C.; Hoarau, C.; Marsais, F. Direct palladium-catalyzed alkenylation, benzylation and alkylation of ethyl oxazole-4carboxylate with alkenyl-, benzyl- and alkyl halides. Org. Biomol. Chem. 2009, 7, 647-650. [CrossRef]

23. Sahnoun, S.; Messaoudi, S.; Brion, J.-D.; Alami, M. Pd/Cu-Catalyzed Direct Alkenylation of Azole Heterocycles with Alkenyl Halides. Eur. J. Org. Chem. 2010, 2010, 6097-6102. [CrossRef]

24. Vabre, R.; Chevot, F.; Legraverend, M.; Piguel, S. Microwave-assisted Pd/Cu-catalyzed C-8 direct alkenylation of purines and related azoles: An alternative access to 6,8,9-trisubstituted purines. J. Org. Chem. 2011, 76, 9542-9547. [CrossRef]

25. Yao, Y.-X.; Fang, D.-M.; Gao, F.; Liang, X.-X. Room-temperature palladium-catalyzed direct 2-alkenylation of azole derivatives with alkenyl bromides. Tetrahedron Lett. 2019, 60, 68-71. [CrossRef]

26. Mahuteau-Betzer, F.; Piguel, S. Synthesis and evaluation of photophysical properties of Series of $\pi$-conjugated oxazole dyes. Tetrahedron Lett. 2013, 54, 3188-3193. [CrossRef]

27. Waldvogel, S.R.; Lips, S.; Selt, M.; Riehl, B.; Kampf, C.J. Electrochemical Arylation Reaction. Chem. Rev. 2018, 118, 6706-6765. [CrossRef] [PubMed]

28. Chen, J.; Lv, S.; Tian, S. Electrochemical Transition-Metal-Catalyzed C-H Bond Functionalization: Electricity as Clean Surrogates of Chemical Oxidants. ChemSusChem 2019, 12, 115-132. [CrossRef] [PubMed] 
29. Yuan, Y.; Lei, A. Electrochemical Oxidative Cross-Coupling with Hydrogen Evolution Reactions. Acc. Chem. Res. 2019, 52, 3309-3324. [CrossRef] [PubMed]

30. Vantourout, J.C. From Bench to Plant: An Opportunity for Transition Metal Paired Electrocatalysis. Org. Process Res. Dev. 2021. [CrossRef]

31. Lessi, M.; Manzini, C.; Minei, P.; Perego, L.A.; Bloino, J.; Egidi, F.; Barone, V.; Pucci, A.; Bellina, F. Synthesis and Optical Properties of Imidazole-Based Fluorophores having High Quantum Yields. ChemPlusChem 2014, 79, 366-370. [CrossRef]

32. Barone, V.; Bellina, F.; Biczysko, M.; Bloino, J.; Fornaro, T.; Latouche, C.; Lessi, M.; Marianetti, G.; Minei, P.; Panattoni, A.; et al. Toward the design of alkynylimidazole fluorophores: Computational and experimental characterization of spectroscopic features in solution and in poly(methyl methacrylate). Phys. Chem. Chem. Phys. 2015, 17, 26710-26723. [CrossRef] [PubMed]

33. Bellina, F.; Manzini, C.; Marianetti, G.; Pezzetta, C.; Fanizza, E.; Lessi, M.; Minei, P.; Barone, V.; Pucci, A. Colourless p-phenylenespaced bis-azoles for luminescent concentrators. Dyes Pigment. 2016, 134, 118-128. [CrossRef]

34. Lessi, M.; Panzetta, G.; Marianetti, G.; Bellina, F. Improved Synthesis of Symmetrical 2,5-Diarylimidazoles by One-Pot PalladiumCatalyzed Direct Arylation Tailored on the Electronic Features of the Aryl Halide. Synthesis 2017, 49, 4676-4686. [CrossRef]

35. Marianetti, G.; Lessi, M.; Barone, V.; Bellina, F.; Pucci, A.; Minei, P. Solar collectors based on luminescent 2,5-diarylimidazoles. Dyes Pigment. 2018, 157, 334-341. [CrossRef]

36. Lessi, M.; Lucci, A.; Cuzzola, A.; Bellina, F. Imidazo-Fused Isoindoles by Pd(II)/Ag(I)-Promoted Intramolecular Dehydrogenative Coupling. Eur. J. Org. Chem. 2020, 2020, 796-802. [CrossRef]

37. Lee, W.C.; Wang, T.H.; Ong, T.G. Ligand promoted Pd-catalyzed dehydrogenative alkenylation of hetereoarenes. Chem. Commun. 2014, 50, 3671-3673. [CrossRef] [PubMed]

38. Kim, H.; Hwang, Y.J.; Han, I.; Joo, J.M. Regioselective C-H alkenylation of imidazoles and its application to the synthesis of unsymmetrically substituted benzimidazoles. Chem. Commun. 2018, 54, 6879-6882. [CrossRef]

39. Miyasaka, M.; Hirano, K.; Satoh, T.; Miura, M. Palladium-catalyzed direct oxidative alkenylation of azoles. J. Org. Chem. 2010, 75, 5421-5424. [CrossRef]

40. Vana, J.; Bartacek, J.; Hanusek, J.; Roithova, J.; Sedlak, M. C-H Functionalizations by Palladium Carboxylates: The Acid Effect. J. Org. Chem. 2019, 84, 12746-12754. [CrossRef]

41. Schubert, W.M.; Keeffe, J.R. Acid-catalyzed hydration of styrenes. J. Am. Chem. Soc. 1972, 94, 559-566. [CrossRef]

42. Grimster, N.P.; Gauntlett, C.; Godfrey, C.R.; Gaunt, M.J. Palladium-catalyzed intermolecular alkenylation of indoles by solventcontrolled regioselective C-H functionalization. Angew. Chem. Int. Ed. 2005, 44, 3125-3129. [CrossRef]

43. Djakovitch, L.; Rouge, P. New homogeneously and heterogeneously [Pd/Cu]-catalysed C3-alkenylation of free $\mathrm{NH}$-indoles. $J$. Mol. Catal. A Chem. 2007, 273, 230-239. [CrossRef]

44. Bellina, F.; Cauteruccio, S.; Mannina, L.; Rossi, R.; Viel, S. Regiocontrolled Synthesis of 1,2-Diaryl-1H-imidazoles by Palladiumand Copper-Mediated Direct Coupling of 1-Aryl-1H-imidazoles with Aryl Halides under Ligandless Conditions. Eur. J. Org. Chem. 2006, 693-703. [CrossRef]

45. Storr, T.E.; Baumann, C.G.; Thatcher, R.J.; De Ornellas, S.; Whitwood, A.C.; Fairlamb, I.J. Pd(0)/Cu(I)-mediated direct arylation of 2'-deoxyadenosines: Mechanistic role of $\mathrm{Cu}(\mathrm{I})$ and reactivity comparisons with related purine nucleosides. J. Org. Chem. 2009, 74, 5810-5821. [CrossRef]

46. Gorelsky, S.I. Tuning the Regioselectivity of Palladium-Catalyzed Direct Arylation of Azoles by Metal Coordination. Organometallics 2012, 31, 794-797. [CrossRef]

47. Bellina, F.; Cauteruccio, S.; Di Fiore, A.; Rossi, R. Regioselective Synthesis of 4,5-Diaryl-1-methyl-1H-imidazoles Including Highly Cytotoxic Derivatives by Pd-Catalyzed Direct C-5 Arylation of 1-Methyl-1H-imidazole with Aryl Bromides. Eur. J. Org. Chem. 2008, 2008, 5436-5445. [CrossRef]

48. Kang, P.; Foote, C.S. Photosensitized oxidation of ${ }^{13} \mathrm{C}^{15} \mathrm{~N}$-labeled imidazole derivatives. J. Am. Chem. Soc. 2002, 124, 9629-9638. [CrossRef] [PubMed]

49. Baghbanzadeh, M.; Pilger, C.; Kappe, C.O. Palladium-catalyzed direct arylation of heteroaromatic compounds: Improved conditions utilizing controlled microwave heating. J. Org. Chem. 2011, 76, 8138-8142. [CrossRef] [PubMed]

50. Molander, G.A.; Brown, A.R. Suzuki-Miyaura cross-coupling reactions of potassium vinyltrifluoroborate with aryl and heteroaryl electrophiles. J. Org. Chem. 2006, 71, 9681-9686. [CrossRef] [PubMed]

51. Petzer, J.P.; Steyn, S.; Castagnoli, K.P.; Chen, J.-F.; Schwarzschild, M.A.; Van der Schyf, C.J.; Castagnoli, N. Inhibition of monoamine oxidase $\mathrm{B}$ by selective adenosine $\mathrm{A}_{2 \mathrm{~A}}$ receptor antagonists. Biorg. Med. Chem. 2003, 11, 1299-1310. [CrossRef]

52. Moorthy, J.N.; Neogi, I. IBX-mediated one-pot synthesis of benzimidazoles from primary alcohols and arylmethyl bromides. Tetrahedron Lett. 2011, 52, 3868-3871. [CrossRef]

53. Kidwai, M.; Bansal, V.; Saxena, A.; Aerry, S.; Mozumdar, S. Cu-Nanoparticles: Efficient catalysts for the oxidative cyclization of Schiffs' bases. Tetrahedron Lett. 2006, 47, 8049-8053. [CrossRef]

54. Moore, T.W.; Sana, K.; Yan, D.; Krumm, S.A.; Thepchatri, P.; Snyder, J.P.; Marengo, J.; Arrendale, R.F.; Prussia, A.J.; Natchus, M.G.; et al. Synthesis and Metabolic Studies of Host Directed Inhibitors for Antiviral Therapy. ACS Med. Chem. Lett. $2013,4,762-767$. [CrossRef] [PubMed]

55. Dutta, S. Synthesis and anthelmintic activity of some novel 2-substituted-4,5-diphenyl imidazoles. Acta Pharm. 2010, 60, 229-235. [CrossRef] [PubMed] 
56. Breslow, R.; Baldwin, S.; Flechtner, T.; Kalicky, P.; Liu, S.; Washburn, W. Remote oxidation of steroids by photolysis of attached benzophenone groups. J. Am. Chem. Soc. 1973, 95, 3251-3262. [CrossRef]

57. Wencel-Delord, J.; Glorius, F. C-H bond activation enables the rapid construction and late-stage diversification of functional molecules. Nat. Chem. 2013, 5, 369-375. [CrossRef]

58. Cernak, T.; Dykstra, K.D.; Tyagarajan, S.; Vachal, P.; Krska, S.W. The medicinal chemist's toolbox for late stage functionalization of drug-like molecules. Chem. Soc. Rev. 2016, 45, 546-576. [CrossRef] [PubMed] 